Discussion Paper No. 10-104

The Importance of Cognitive and Social Skills for the Duration of Unemployment

Verena Niepel

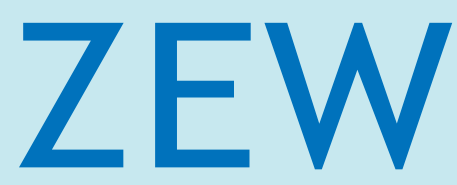

Zentrum für Europäische Wirtschaftsforschung $\mathrm{GmbH}$

Centre for European Economic Research 
Discussion Paper No. 10-104

\title{
The Importance of Cognitive and Social Skills for the Duration of Unemployment
}

\author{
Verena Niepel
}

Download this ZEW Discussion Paper from our ftp server:

ftp://ftp.zew.de/pub/zew-docs/dp/dp10104.pdf

Die Discussion Papers dienen einer möglichst schnellen Verbreitung von neueren Forschungsarbeiten des ZEW. Die Beiträge liegen in alleiniger Verantwortung der Autoren und stellen nicht notwendigerweise die Meinung des ZEW dar.

Discussion Papers are intended to make results of ZEW research promptly available to other economists in order to encourage discussion and suggestions for revisions. The authors are solely responsible for the contents which do not necessarily represent the opinion of the ZEW. 


\section{Non-technical Summary}

The present study analyses the role that human capital in childhood plays for the duration of an unemployment spell in adolescence and early adulthood. It thus asks the question how early in life we can detect skills that will be important for the probability of finding employment later in life. In particular, it analyses not only the relevance of cognitive skills, but also explores the importance of social skills, being a further dimension of human capital that might be targeted by policy measures. The empirical analysis builds on data from the National Child Development Study, a cohort study based on all individuals born in Great Britain in a single week in March 1958. As a measure for social skills, I rely on teacher ratings of children's behaviour using the Bristol Social Adjustment Guides. In addition, four tests administered to the children in school are used to measure cognitive skills.

The results show that higher cognitive and social skills at the age of 7 are associated with an increased probability of making a transition from unemployment to employment during an individual's first unemployment spell. Among men, only those in the lower part of the social skill distribution benefit from an increase in cognitive or social skills. Controlling for individuals' educational attainment leaves the qualitative results unchanged. Furthermore, the effects do not seem to be driven by observable differences in family background, parents' activities with the child or school characteristics.

The findings of this study suggest that policy measures aiming at increasing early cognitive and social skills contribute also to reducing the risk of long unemployment episodes in adolescence and early adulthood. Moreover, in light of recent debates on achievements in international pupil tests that often focus on cognitive skills, this study provides additional evidence showing that one should not neglect investing in children's social skills since they are related to later outcomes in a similar way as cognitive skills. 


\section{Das Wichtigste in Kürze}

Die vorliegende Studie erforscht die Rolle von Fähigkeiten in der Kindheit für die Dauer der ersten Arbeitslosigkeitsperiode im Jugend- und frühen Erwachsenenalter. Es wird somit untersucht, ob bereits früh im Lebensverlauf Fähigkeiten entdeckt werden können, die im späteren Leben für die Wahrscheinlichkeit eine Beschäftigung zu finden relevant werden. Hierzu wird insbesondere auf die Unterscheidung zwischen kognitiven und sozialen Fähigkeiten eingegangen, da diese unter Umständen verschiedene Zielgrößen für mögliche Politikmaßnahmen von seiten des Staates darstellen. Die empirische Analyse beruht auf Daten einer Kohortenstudie aus Großbritannien, die alle Personen, die in einer bestimmten Woche im März 1958 geboren wurden, an verschiedenen Zeitpunkten im Leben befragt. Soziale Fähigkeiten werden anhand einer Beurteilung des Verhaltens der Kinder durch deren Lehrer gemessen. Das Maß für kognitive Fähigkeiten setzt sich aus vier in der Schule absolvierten Tests zusammen.

Die Analysen zeigen, dass höhere kognitive und soziale Fähigkeiten im Alter von sieben Jahren mit einer erhöhten Wahrscheinlichkeit Arbeitslosigkeit zu verlassen und eine Beschäftigung zu finden einhergehen. In Bezug auf Männer scheint der Zusammenhang allerdings hauptsächlich für diejenigen zu gelten, die in der Kindheit niedrige soziale Fähigkeiten hatten. Die qualitativen Ergebnisse ändern sich durch die Berücksichtigung des erreichten Bildungsabschlusses nicht. Zudem sind die Effekte nicht allein durch beobachtbare Unterschiede im familiären Hintergrund der Individuen, elterliches Engagement oder Schulcharakteristika zu erklären.

Die Ergebnisse dieser Studie deuten somit darauf hin, dass Maßnahmen, die zur Erhöhung von kognitiven und sozialen Fähigkeiten in der Kindheit beitragen, auch das Risiko langer Arbeitslosigkeitsperioden im Jugend- und frühen Erwachsenenalter verringern. Im Lichte der Debatten über das Abschneiden in internationalen Schülerleistungstests, die sich oft auf Unterschiede in kognitiven Fähigkeiten konzentrieren, liefert diese Studie weitere Evidenz dafür, dass Investitionen in die sozialen Fähigkeiten von Kindern nicht außer Acht gelassen werden sollten. 


\title{
The Importance of Cognitive and Social Skills for the Duration of Unemployment
}

\author{
Verena Niepel*
}

December 2010

\begin{abstract}
This paper studies how cognitive and social skills in childhood are related to the duration of unemployment in adolescence and early adulthood. I estimate a flexible proportional hazard rate model for the probability of making a transition from unemployment to employment during an individual's first unemployment spell. The analysis is based on British cohort data from the National Child Development Study. Results show that higher cognitive and social skills at the age of 7 are associated with an increased probability of finding employment, even when controlling for educational attainment. For men, these effects are mostly driven by individuals with low social skills. The results are robust to controlling for family background, parenting activities and school characteristics.
\end{abstract}

JEL Classification: C41, J24, J64

Keywords: unemployment duration, social skills, noncognitive skills, cognitive skills, early skills

${ }^{*}$ Centre for European Economic Research (ZEW) and Centre for Doctoral Studies in Economics (CDSE), University of Mannheim. Contact: niepel@zew.de; L7, 1, 68161 Mannheim.

I gratefully acknowledge support from the Leibniz Association, Bonn, in the research network "NonCognitive Skills: Acquisition and Economic Consequences". I also thank Jennifer Abel-Koch, Bodo Aretz, Gerard van den Berg, Stephan Dlugosz, Philipp Eisenhauer, Bernd Fitzenberger, Markus Frölich, Christina Gathmann, Andrea Mühlenweg, Andras Niedermayer, Pia Pinger, Friedhelm Pfeiffer, Isabel Ruhmer, Maresa Sprietsma, Arne Uhlendorff and the seminar participants at ZEW, University of Mannheim and University of Uppsala for valuable discussions and comments on earlier versions of this paper. Moreover, I would like to thank Lennart Ziegler for his fine research assistance. I am grateful to the UK Data Archive and the Centre for Longitudinal Studies for supplying the National Child Development Study and to the funders of this study. All remaining errors are my own. 


\section{Introduction}

Understanding which individual factors influence the duration of an unemployment spell is important for designing policy measures that help individuals to find employment. Recent research indicates that noncognitive skills, such as social skills or personality traits, as well as cognitive skills influence wages, employment, educational and social outcomes (see for example Heckman et al. (2006); Bowles et al. (2001); Blomeyer et al. (2009)). However, only little is known about the influence of cognitive and noncognitive skills on the duration of an unemployment spell. Existing studies show that certain noncognitive skills are related to the probability of making a transition from unemployment to employment (Uhlendorff, 2004; Uysal and Pohlmeier, 2009; Lindqvist and Vestman, 2010; DellaVigna and Paserman, 2005). Yet, only Lindqvist and Vestman (2010) and DellaVigna and Paserman (2005) include both cognitive and noncognitive skills in the estimation, finding different results on the effect of cognitive skills. If both dimensions of skills are correlated, not controlling for cognitive skills might overestimate the effect of noncognitive skills.

Concerning the optimal timing of social policy measures, Cunha et al. (2006) summarise evidence showing that interventions targeting human capital early in life are more efficient in ameliorating outcomes of disadvantaged individuals than later attempts to do so. Correspondingly, many papers have pointed out that already early skills predict socio-economic outcomes later in life (see for example Currie and Thomas (2001), Carneiro et al. (2007)). In particular, some studies show that cognitive and noncognitive skills measured in childhood are related to different measures of time spend in unemployment in adolescence and early adulthood. For example, Gregg (2001) and Gregg and Machin (2000) show that social skills at the age of 7 are associated with the overall number of months spent unemployed in early adulthood. However, by aggregating all unemployment episodes into one measure, the authors do not distinguish between the relevance of skills in childhood for the probability of becoming unemployed and the probability of finding a job.

The present paper contributes by studying the importance of human capital in childhood for the duration of an unemployment spell in early adulthood for men and women. In particular, it analyses not only the relevance of cognitive skills, but also explores the importance of social skills, being a further dimension of human capital that might 
be targeted with policy measures. I estimate a proportional hazard rate model for the probability of making a transition from unemployment to employment during an individual's first unemployment spell experienced before the age of 23. This approach has three main advantages. First, it disentangles how skills in childhood are associated with the probability of leaving unemployment from how they relate to the probability of becoming unemployed. Second, I specifically look at the probability of being successful at finding a job, which should be distinguished from other reasons for leaving unemployment, such as leaving the labour force. Third, since experiencing unemployment might influence noncognitive skills (see e.g. Goldsmith et al. (1995)), analysing skills measured before individuals have entered the labour market circumvents reverse causality issues.

The empirical analysis builds on data from the National Child Development Study (NCDS), a cohort study based on all individuals born in Great Britain in a single week in March 1958. As a measure for social skills I rely on teacher ratings of children's behaviour using the Bristol Social Adjustment Guides (BSAG). In addition, four tests administered to the children in school are used to measure cognitive skills at the age of 7.

The results show that higher cognitive and social skills at the age of 7 are associated with an increased probability of making a transition from unemployment to employment during an individual's first unemployment spell. For men, there is a significant negative interaction effect between cognitive and social skills. Therefore, only those in the lower part of the cognitive skill distribution benefit from an increase in social skills and vice versa. For women, this inverse interaction effect is less pronounced. Furthermore, concerning men, the positive effect of an increase in social skills seems to be driven mostly by individuals with low social skills. Including educational attainment in the estimation slightly reduces the estimated hazard ratios but leaves the qualitative results unchanged. The estimates are robust to controlling for parenting activities, family background and school characteristics at the age of 7 . Moreover, I find that also skills measured at the age of 11 are related to the probability of finding employment. However, the point estimates for age 11 social skills are smaller and of lower statistical significance than those for age 7 social skills.

The paper is organised as follows: Section 2 briefly surveys previous findings in the literature. Section 3 introduces the dataset and skill measures used in this study and presents descriptive statistics. Possible effects of skills in childhood on the duration of 
unemployment are discussed in Section 4. Section 5 presents the econometric model, followed by estimation results in Section 6. Section 7 summarizes the main findings and concludes.

\section{Existing Evidence}

Recent studies on the relation between noncognitive skills and the duration of an unemployment spell have used German, Swedish and US datasets, measuring skills in late adolescence and adulthood. Uhlendorff (2004) uses the German Socio-Economic Panel (SOEP) to analyse the effect of an individual's locus of control and membership in political associations or clubs on the duration of an unemployment spell for men. He estimates a non-proportional Cox model and uses unemployment spells that occurred after measuring locus of control, thereby avoiding reverse causality issues. His results show that locus of control has a large effect on the duration of an unemployment spell for men living in the western part of Germany, while there is no significant association for those living in the eastern part. Uysal and Pohlmeier (2009) also use the SOEP to investigate the relation between noncognitive skills as measured by the Big Five and the duration of employment and unemployment. They analyse all unemployment spells that occurred between the years 1983 and 2006 for both men and women and show that the personality factors conscientiousness and openness to experience increase the chances of finding a job, while neuroticism decreases them. However, the statistical significance of these results differs for men and women. In contrast to the studies using German data, Lindqvist and Vestman (2010) estimate the duration of unemployment controlling for both cognitive and noncognitive skills. They use Swedish register data on wages and employment biographies of men in 2006, thereby observing individuals at different stages in their working life. Skills are measured via tests and interviews conducted in the course of the military enlistment process around the age of 18. Lindqvist and Vestman find that higher noncognitive skills significantly decrease the duration of unemployment while cognitive skills have no statistically significant influence. DellaVigna and Paserman (2005) use the National Longitudinal Study of Youth and the Panel Study of Income Dynamics to show that several indicators of impatient behaviour, such as smoking and the interviewer's rating of an individual's impatience, are associated with a decreased 
exit rate from unemployment. They report that also higher cognitive skills are related to an increased probability of leaving unemployment.

In addition, several studies have investigated the relationship between noncognitive skills and other measures of unemployment, in particular the probability of being unemployed at a certain point in time and cumulative work experience (e.g. Carneiro et al. (2007) and Heckman et al. (2006)), the probability of experiencing unemployment of a certain duration up to a certain age (see for example Feinstein (2000) and Hobcraft (2000)) or the overall amount of time spent unemployed in a certain period (e.g. Gregg and Machin (2000), Gregg (2001) and Caspi et al. (1998)). Carneiro et al. (2007) use the NCDS and find that the probability of being unemployed at the age of 42 and cumulative work experience between the age of 23 and 42 are influenced by cognitive and social skills in childhood. They show that this effect persists even after controlling for educational attainment. Heckman et al. (2006) use data from the USA and find similar results for cognitive and noncognitive skills measured in adolescence and early adulthood.

Gregg (2001) analyses the scarring effect of the number of months spent unemployed between the age of 16 and 23 for experiencing unemployment later in life using the NCDS. In doing so, he also estimates a Tobit model on the number of months spent unemployed between the age of 16 and 23 and finds that social skills at the age of 7 increase the number of months spent unemployed, while cognitive skills are not a significant predictor. Similarly, Caspi et al. (1998) find that intelligence tests and behavioural indicators in childhood are predictors for the number of months spent unemployed between the age of 15 and 21, using a dataset from New Zealand. These studies do not distinguish between the importance of skills in childhood for the probability of becoming unemployed and their relevance for the duration of an unemployment spell, which is what the present paper aims at explaining.

Using the 1970 British Cohort Study, Feinstein (2000) analyses the probability of having an unemployment spell that lasts for more than 4 months before the age of 26 and, for individuals for which this is the case, the probability that their longest spell lasts for more than one year. The first outcome is thus comprised of the probability of becoming unemployed and the probability of experiencing an unemployment spell of at least 4 months. He finds that the math score and certain noncognitive skills at the age of 10 are related to the probability of being unemployed for more than 4 months. However, for the conditional probability of experiencing a spell of more than 12 months, he finds 
no predictive power of early skills for men and reports that a different set of noncognitive skills than in the first estimation are significant for women. These mixed results point out that early skills might be of different importance for the probability of becoming unemployed and for the probability of finding new employment. They thus emphasise the relevance of modeling the probability of making a transition from unemployment to employment in a duration model framework in order to achieve a deeper understanding of the effect of early skills.

\section{Data and Descriptive Statistics}

\section{Data}

This analysis uses data from the National Child Development Study. The NCDS builds upon the Perinatal Mortality Survey (PMS) which includes all women who gave birth in Great Britain in a single week in March 1958, resulting in a dataset with information on 17.414 individuals. These form the basis for the following waves of the NCDS that have been carried out when the study members were aged 7, 11, 16, 23, 33, 42, 46 and 50. Across the different waves, information was provided by the children's parents, teachers, the schools' health service and the cohort members themselves. The dataset includes detailed information on the family background of the individuals, skills in childhood, educational attainment, family status and on the employment history.

At the age of 23, individuals were asked to report their main activity since May 1974 in a monthly diary. The diary contains information on periods in unemployment, employment and time spent out of the labour force, including education. Unemployment is defined as a time period in which the individual did not have a job but was willing to start work or was registered as unemployed. Furthermore, holidays or vacations during full-time education are not included in this definition. Using this information, I construct individual unemployment spells. In months with more than one labour market status the dominant one is recorded. Therefore, only periods of unemployment that lasted for more than two weeks show up in the data.

The measures for cognitive and social skills in childhood were obtained at the cohort members' schools when they were 7 years old. Cognitive skills were assessed using four tests (Centre for Longitudinal Studies, 2005). In the Southgate Group Reading Test (Southgate, 1962), children were asked to pick one out of five words on a list to describe 
a drawing or a word that the teacher read out to them. The Copying Designs Test assesses children's perceptuo-motor ability by letting them copy geometric figures and taking a writing sample. In order to assess the children's general perceptual ability, they were asked to draw a man in the Drawing-A-Man Test (Goodenough, 1926). Lastly, the Problem Arithmetic Test (Pringle et al., 1966) consisted of ten arithmetic exercises. I construct a total score for cognitive skills by summing up the normalized scores on each of the tests and then normalizing the total to have mean zero and variance one.

Social skills are measured using the Bristol Social Adjustment Guides. This instrument assesses children's behaviour in school and is supposed to capture behavioural disturbances in responding to different social situations (Stott, 1974) ${ }^{1}$. For example, a child might act aggressively or rather withdrawn and inhibited when confronted with new situations. The BSAG was measured by handing out a list of 146 phrases that describe behaviour of children to the teachers of the cohort members ${ }^{2}$. They were asked to underline the phrases that best describe the child. The different aspects of behaviour are grouped into twelve syndromes: unforthcomingness, withdrawal, depression, anxiety for acceptance by children, anxiety for acceptance by adults, hostility towards adults, hostility towards children, writing-off adults and adult standards, restlessness, inconsequential behaviour, miscellaneous symptoms and miscellaneous nervous symptoms. By adding up the respective number of underlined phrases, twelve syndrome scores have been constructed by the data providers. Following Carneiro et al. (2007), I use the overall BSAG score, defined as the sum of the syndrome scores, as my measure for social skills and reverse the sign such that a higher value indicates more skills. In addition, I normalize it to have mean zero and variance one in the sample. Figure 1 shows kernel density estimates of the resulting measures for cognitive and social skills. One can see that the density of social skills is strongly skewed to the left, that is many individuals have a high social skills score, while the density of cognitive skills more closely resembles a bell-shape.

\footnotetext{
${ }^{1}$ For further reading on the BSAG see for example Davie (1973) or Ghodsian (1977).

${ }^{2}$ Achenbach et al. (1987) investigate correlations between assessments of behavioural problems in children that were performed by different informants, such as teachers, parents, health visitors or the children themselves. They carry out a meta-analysis and find that, within the group of informants other than the children themselves, the correlation between the ratings is highest among teachers.
} 
The estimation sample includes the first unemployment spell of all individuals that provided sufficient information on their employment history in NCDS $4^{3}$ and for whom there is information on cognitive and social skills at the age of 7 . Individuals in the highest and lowest percentile of cognitive skills are dropped from the sample in order to avoid results being driven by outliers. Concerning social skills, only the lowest percentile is dropped since $10 \%$ of the sample have zero points on the original BSAG score, which is the highest possible score for social skills. This leaves me with 10,130 cohort members. 4,287 of these had at least one unemployment spell before the age of 23 and form the sample used for the estimations ${ }^{4}$. Unemployment spells lasting longer than 24 months, which is the case for about $2 \%$ of all spells, are censored at 24 months. Details on the derivation of covariates are given in Appendix A.

\section{Descriptive Statistics}

Table 1 displays descriptive statistics on the first unemployment spell, cognitive and social skills and background covariates. The statistics on the covariates refer to the values at the beginning of the spell. One can see that, on average, women have higher age 7 cognitive and social skills than men. Education is measured as highest qualification achieved until the beginning of the unemployment spell: 44 percent of men and 38 percent of women have a qualification below O-Levels or the equivalent National Vocational Qualification (NVQ) level 2 while 10 percent of men and 14 percent of women are in the highest education category and have achieved a higher qualification or degree, equivalent to NVQ levels 4,5 and 6. Moreover, 31 percent of men and 35 percent of women have not been employed between leaving full-time education and the beginning of their first unemployment spell. About half of all unemployment spells start between 1974 and 1976, which is when the cohort members having obtained A-Levels or below usually leave school.

The mean duration of unemployment is 4.37 months for men and 4.76 for women, the median is 3 months for both. However, not all spells end in a transition to employment: 8 percent of all male and 6 percent of all female spells are censored by the interview at the age of 23. Furthermore, one percent of male and two percent of female spells are

\footnotetext{
${ }^{3}$ Those that did not provide information for more than 6 months of their employment history are dropped from the sample.

${ }^{4}$ Appendix $\mathrm{C}$ discusses the probability of experiencing at least one unemployment spell before the age of 23 and thus being in the sample used for the estimations.
} 
Table 1: Descriptive statistics

\begin{tabular}{|c|c|c|c|c|}
\hline & \multicolumn{2}{|c|}{ men } & \multicolumn{2}{|c|}{ women } \\
\hline & mean & $\begin{array}{l}\text { standard } \\
\text { deviation }\end{array}$ & mean & $\begin{array}{l}\text { standard } \\
\text { deviation }\end{array}$ \\
\hline duration of unemployment spell & 4.37 & 4.59 & 4.76 & 4.83 \\
\hline spell censored & 0.17 & & 0.21 & \\
\hline - by interview & 0.08 & & 0.06 & \\
\hline - at 24 months & 0.01 & & 0.02 & \\
\hline - following activity unknown & 0.01 & & 0.01 & \\
\hline - by transition out of the labour force & 0.07 & & 0.12 & \\
\hline - - thereof transition into education & 0.05 & & 0.04 & \\
\hline cognitive skills & -0.05 & 1.02 & 0.05 & 0.98 \\
\hline social skills & -0.17 & 1.05 & 0.18 & 0.91 \\
\hline less than O-Levels / NVQ 0-1 & 0.44 & & 0.38 & \\
\hline O-Levels/ NVQ 2 & 0.28 & & 0.38 & \\
\hline A-Levels/ NVQ 3 & 0.18 & & 0.11 & \\
\hline degree/ NVQ 4-6 & 0.10 & & 0.14 & \\
\hline no exact education biography & 0.03 & & 0.02 & \\
\hline married & 0.08 & & 0.15 & \\
\hline parent & 0.05 & & 0.06 & \\
\hline \multicolumn{5}{|c|}{ socio-economic status of father at the age of 7} \\
\hline low SES & 0.26 & & 0.24 & \\
\hline high SES & 0.16 & & 0.17 & \\
\hline medium SES & 0.50 & & 0.52 & \\
\hline no male head of household & 0.03 & & 0.02 & \\
\hline SES missing & 0.05 & & 0.05 & \\
\hline no previous employment & 0.31 & & 0.35 & \\
\hline autumn or winter & 0.36 & & 0.36 & \\
\hline claimant count rate & 4.78 & 1.77 & 4.65 & 1.6 \\
\hline \multicolumn{5}{|l|}{ year spell started in } \\
\hline 1974 & 0.17 & & 0.15 & \\
\hline 1975 & 0.14 & & 0.18 & \\
\hline 1976 & 0.16 & & 0.20 & \\
\hline 1977 & 0.11 & & 0.11 & \\
\hline 1978 & 0.07 & & 0.08 & \\
\hline 1979 & 0.11 & & 0.10 & \\
\hline 1980 & 0.14 & & 0.12 & \\
\hline 1981 & 0.10 & & 0.07 & \\
\hline \multicolumn{5}{|l|}{ region of residence at the age of 16} \\
\hline Wales & 0.07 & & 0.07 & \\
\hline North & 0.09 & & 0.10 & \\
\hline North West & 0.15 & & 0.15 & \\
\hline E \& W.Riding & 0.09 & & 0.09 & \\
\hline North Midlands & 0.07 & & 0.07 & \\
\hline Midlands & 0.10 & & 0.11 & \\
\hline East & 0.08 & & 0.06 & \\
\hline South East & 0.13 & & 0.12 & \\
\hline South & 0.05 & & 0.06 & \\
\hline South West & 0.06 & & 0.06 & \\
\hline Scotland & 0.11 & & 0.11 & \\
\hline number of observations & 2,223 & & 2,064 & \\
\hline
\end{tabular}


artificially censored after 24 months. The activity following the unemployment spell is unknown for another percent of spells. Lastly, 7 percent of male and 12 percent of female unemployment spells are followed by a period out of the labour force. Thereof, 5 and 4 percent, respectively, are transitions to education. Overall, 17 percent of male and 21 percent of female spells do not end with a transition to employment and will be treated as right censored in the estimation. Hence, it is important to use an econometric model that takes incomplete spells into account, such as the proportional hazard rate model.

Figure 2 shows Kaplan-Meier estimates of survival functions for individuals with above and below average cognitive and social skills. One can see that most individuals leave unemployment within the first 12 months. Of all unemployment spells, 93 percent end in the first year. Furthermore, the estimated survival function for individuals with above average cognitive skills lies slightly to the left of the one for those with lower cognitive skills. This shows that individuals with above average cognitive skills at the age of 7 leave unemployment slightly faster than those with lower cognitive skills. The corresponding graph for social skills is similar, however, the difference between the two survival functions is smaller. Nevertheless, a log-rank test rejects the null hypothesis of equality of the survival functions of individuals with below and above average skills at the $99 \%$ signifiance level for both cognitive and social skills ${ }^{5}$.

\section{Hypotheses}

This section discusses potential mechanisms through which cognitive and social skills at the age of 7 may influence the duration of unemployment.

Cognitive and social skills at the age of 7 are likely to influence the duration of unemployment mainly via two channels: First, higher cognitive and social skills at the age of 7 are associated with higher skills in adolescence and adulthood (see e.g. Heckman (2008), Borghans et al. (2008), Cunha and Heckman (2007), Caspi et al. (2003) and Dennissen

\footnotetext{
${ }^{5}$ The test statistic is 19.04 for cognitive skills and 9.21 for social skills.
} 
et al. $\left.(2008)^{6}\right)$, which may affect the length of an unemployment spell. Second, higher skills in childhood are positively related to the likelihood of achieving a higher education (see e.g. Heckman et al. (2006) and Carneiro et al. (2008)), which in turn might have an impact on the duration of unemployment (see e.g. Nickell (1979) and Kiefer (1985)). Thus, deriving hypotheses on the influence of early cognitive and social skills on the probability of finding a job requires a discussion of the effects of education and skills in adulthood on this probability. In the following, this is done by making use of predictions from job search theory (see e.g. Mortensen (1986) and Cahuc and Zylberberg (2004)) and evidence from the empirical literature on unemployment duration.

Adult cognitive and social skills are likely to be relevant for the duration of an unemployment spell by increasing an individual's productivity. The evidence on the association of cognitive and social skills with wages points in this direction (Osborne, 2000; Heckman et al., 2006; Carneiro et al., 2007). Cognitive skills, such as the capacity to process information, language skills and general reasoning skills, are likely to be important for performance in most tasks in working life. At the same time, social skills may enable individuals to adjust to a new work environment more easily and thereby start focusing on the specific tasks of a job more quickly. Moreover, individuals with higher social skills might be more productive in working in teams and interacting with colleagues. Besides being more productive, individuals with higher social skills are likely to have a larger social network, which they can use when searching for employment. They might also incur a lower disutility from working, if they are more able to cope with stressful situations that involve dealing with other people or complex problems.

For these reasons, higher adult cognitive and social skills are likely to increase the number of jobs and the average wage offered to an individual. Not considering the indirect effect on the reservation wage, higher cognitive and social skills therefore increase the probability of finding a job. However, both a higher number of job offers and higher wage offers increase an individual's reservation wage. This has a negative effect on the

\footnotetext{
${ }^{6}$ Dennissen et al. (2008) and Caspi et al. (2003) analyse the correlation between behaviour and personality assessed in childhood and in adulthood. The authors of the first study report positive correlations between being assessed as undercontroller or overcontroller as opposed to resilient at the age of 4 to 6 and scores in shyness and aggressiveness in early adulthood. Caspi et al. (2003) report correlations between the temperamental types undercontrolled and inhibited, assessed at the age of 3 , and the Big Five personality dimensions (see e.g. Costa and McCrae (1992)) assessed at the age of 26. The scale neuroticism is positively related while openness to experience is negatively related to both temperamental types mentioned. Moreover, the scales agreeableness and conscientiousness are negatively related to the type undercontrolled and the type inhibited is negatively related to extraversion.
} 
exit rate to employment, rendering the overall effect ambiguous. Yet, findings in the theoretical and empirical literature suggest that the direct positive effects dominate the indirect negative effect in many cases ${ }^{7}$. Higher cognitive and social skills at the beginning of an unemployment spell are thus likely to exert a positive effect on the probability of making a transition from unemployment to employment.

A higher educational degree may increase the number of employment possibilities since individuals can apply also for jobs requiring a lower level of education. Moreover, education may serve as a productivity signal to employers. Assuming that the job search activity stays constant, these factors increase the job offer arrival rate. At the same time, higher educational degrees transfer into higher wages. This leads to an increase in the reservation wage, which is why the effect of a higher educational attainment on the exit rate is ambiguous, too. Previous studies on the duration of unemployment in the UK found mostly positive effects of education on the probability of leaving unemployment, although they were not always statistically significant (Kiefer, 1985; Nickell, 1979; Narendranathan and Stewart, 1993; Arulampalam and Stewart, 1995). Taking this into account and following the argument laid out in the last paragraph, a higher education is likely to increase the probability of leaving unemployment.

Summarising this section, the direction and relevance of the effect of cognitive and social skills in childhood remain an empirical question. Nevertheless, higher skills in childhood are likely to increase the probability of leaving unemployment both via increasing later skills and via increasing the probability of achieving a higher education.

\section{Econometric Model}

The empirical analysis uses a proportional hazard rate model for grouped duration data as proposed by Prentice and Gloeckler (1978). This method models the probability of making a transition from unemployment to employment for each point during the unemployment spell in a continuous time framework and adjusts for the monthly structure of the observed data.

\footnotetext{
${ }^{7}$ Van den Berg (1994) showed in the framework of a basic job search model that a large class of wage offer distributions satisfy conditions such that the effect of a higher offer arrival rate outweighs that of a higher reservation wage. That is, an increasing job offer arrival rate leads to an increase in the exit rate from unemployment. Devine and Kiefer (1991) conclude in their review of the literature that the job offer arrival rate seems to be at least as important as the reservation wage for empirically observed durations of unemployment spells.
} 
Unemployment spells end either in transitions to employment or in transitions to another state, being out of the labour force ${ }^{8}$ or an activity for which the state is unknown. The observed duration corresponds to the minimum of the two. In addition, spells may be right censored if the individual is unemployed at the time of the interview. This paper focuses on the duration until an individual finds a job and treats unemployment spells that end in a transition to another state as right censored at the time of transition. It is assumed that the duration until censoring is independent of the duration until a transition to employment, given the vector of covariates used in this study.

The continuous time hazard function for individual $i$, that is the probability of making a transition to employment at time $t$, is modeled as the product of the baseline hazard $\lambda(t)$, capturing the duration dependence, and a term that captures the effect of covariates:

$$
h\left(t, Z_{i t}\right)=\lambda(t) \cdot \exp \left\{Z_{i t}^{\prime} \beta\right\}
$$

The covariate vector $Z_{i t}$ includes time-varying and time-constant variables and a constant as its first element. The corresponding coefficient vector is denoted by $\beta$ and the complete time path of covariates until time $t$ by $\left\{Z_{i t}\right\}$. The baseline hazard is modeled as a piecewise constant function in order to avoid imposing strong functional form assumptions:

$$
\lambda(t)=\exp \left\{\sum_{l=2}^{L} I_{l}(t) \cdot \alpha_{l}\right\}
$$

Each $I_{l}(t)$, for $l=2, \ldots, L$, denotes an indicator variable equal to one if $t$ lies in the time period $l$ and zero otherwise. $\alpha_{l}$ are the corresponding coefficients. I include indicator variables for every month in the first year in unemployment and one indicator for the second year in the estimation ${ }^{9}$.

In the data, durations are observed in monthly intervals $\left[t_{g}-1, t_{g}\right)$ for $g=1, \ldots, 24$. In order to adjust for the grouping structure, the covariate vector $Z_{i t}$ is assumed to be constant within each month $g$ and denoted by $Z_{i g}$. The grouped hazard function $h^{d}\left(g, Z_{i g}\right)$

\footnotetext{
${ }^{8}$ Participation in active labour market policy programmes are grouped into this category as well.

${ }^{9}$ The indicator for the first month is left out of the estimation and used as reference category. Allowing for a more flexible shape for the second year of the spell does not change the results, which may be due to the small number of spells that last longer than 12 months.
} 
denotes the probability of making a transition to employment in the $g^{\text {th }}$ interval, that is in the interval $\left[t_{g}-1, t_{g}\right)$, given survival until the beginning of the $g^{\text {th }}$ interval:

$$
h^{d}\left(g, Z_{i g}\right)=\operatorname{Prob}\left(T \in\left[t_{g}-1, t_{g}\right) \mid T \geq t_{g}-1, Z_{i g}\right)
$$

The grouped survival function denotes the probability of surviving through the $g^{\text {th }}$ interval:

$$
S^{d}\left(g,\left\{Z_{i g}\right\}\right)=\operatorname{Prob}\left(T \geq t_{g} \mid\left\{Z_{i g}\right\}\right)
$$

Following Jenkins (1995), the grouped survival and hazard functions can be expressed in terms of the parameters of the continuous time model in the following way:

$$
\begin{aligned}
h^{d}\left(g, Z_{i g}\right) & =1-\exp \left\{-\exp \left\{Z_{i g}^{\prime} \beta+\gamma_{g}\right\}\right\} \\
S^{d}\left(g,\left\{Z_{i g}\right\}\right) & =\prod_{j=1}^{g}\left(1-h^{d}\left(j, Z_{i j}\right)\right)
\end{aligned}
$$

with

$$
\gamma_{g}=\ln \int_{t_{g}-1}^{t_{g}} \lambda(u) d u
$$

Letting $\delta_{i}=1$ denote a transition to employment and $\delta_{i}=0$ a censored spell, the log-likelihood reads

$$
\begin{aligned}
\log L\left(\beta, \gamma \mid g_{i},\left\{Z_{i g_{i}}\right\}\right) & =\sum_{i=1}^{N} \delta_{i} \cdot \log \left[h^{d}\left(g_{i}, Z_{i g_{i}}\right) \cdot \prod_{j=1}^{g_{i}-1}\left(1-h^{d}\left(j, Z_{i j}\right)\right)\right] \\
& +\left(1-\delta_{i}\right) \cdot \log \left[\prod_{j=1}^{g_{i}}\left(1-h^{d}\left(j, Z_{i j}\right)\right)\right]
\end{aligned}
$$

where $\gamma$ denotes the vector containing all $\gamma_{g}$.

As derived in Jenkins (1995), this log-likelihood may also be written and estimated in the form of a sequential binary choice model. To see this, define $y_{i g}=1$ if there is a transition to employment in interval $\mathrm{g}$ and zero otherwise:

$$
\log L\left(\beta, \gamma \mid g_{i},\left\{Z_{i g_{i}}\right\}\right)=\sum_{i=1}^{N} \sum_{j=1}^{g_{i}} y_{i j} \cdot \log \left[h^{d}\left(j, Z_{i j}\right)\right]+\left(1-y_{i j}\right) \log \left[1-h^{d}\left(j, Z_{i j}\right)\right]
$$


Given the formula for the grouped hazard in Equation 5, this corresponds to the loglikelihood in a generalized linear model with a binary dependent variable and complementary log-log link function (Jenkins, 1995). This model is estimated using maximum likelihood.

\section{Results}

Table 2 presents the estimation results, displaying hazard ratios ${ }^{10}$ and corresponding standard errors in parentheses. I estimate the model separately for men and women, as the determinants of the duration of unemployment may differ by gender. The first and third column present results from estimations not controlling for education. The skill variables will therefore capture the overall effect of skills at the age of 7 on the hazard, including the effect that goes through the channel of achieving a higher education. Column 2 and 4 show results controlling for educational attainment.

In all estimations, I control for whether the individual is married or has children at the beginning of the spell, has had a job since leaving full time education and for the socio-economic status (SES) of the father or male head of household when the child was 7 years old. Furthermore, I include the monthly claimant count rate of Great Britain, whether it is autumn or winter as opposed to spring or summer, region of residence at the age of $16^{11}$, year dummies in order to control for macroeconomic changes in the economy and changes in the social security system ${ }^{12}$ and indicator variables capturing the duration dependence.

The first and third column of Table 2 show that social skills at the age of 7 have a significant association with the probability of leaving unemployment both for men and women. An increase in social skills of one standard deviation increases the probability of finding a job at each point during the spell by 6.6 percent for men and 11.8 percent

\footnotetext{
${ }^{10}$ The hazard ratio measures the change in the hazard rate associated with a change in the corresponding variable by one unit, holding all other variables fixed. It is calculated by exponentiating the estimated coefficient.

${ }^{11}$ If this is not available because the individual did not respond in the corresponding interview, I use the region of residence at the age of 11 .

${ }^{12}$ See Clasen (1994) and Mittelstädt and Veil (1975) for a detailed description of the British social security system in the 1970's and 80's. Clasen (1994) reports that there were no changes in the eligibility or entitlement period of unemployment benefits between 1973 and 1981, which is the relevant period for this analysis. However, there were changes in the level of benefits and the benefit rates, which basically eroded the real value of unemployment insurance benefits and the earnings-related supplement over time.
} 
Table 2: Estimation results of duration model

\begin{tabular}{|c|c|c|c|c|}
\hline & \multicolumn{2}{|c|}{ men } & \multicolumn{2}{|c|}{ women } \\
\hline & $\begin{array}{l}\text { without } \\
\text { education }\end{array}$ & $\begin{array}{c}\text { with } \\
\text { education }\end{array}$ & $\begin{array}{c}\text { without } \\
\text { education }\end{array}$ & $\begin{array}{c}\text { with } \\
\text { education }\end{array}$ \\
\hline social skills & $\begin{array}{l}1.066^{* *} \\
(0.028)\end{array}$ & $\begin{array}{l}1.060^{* *} \\
(0.028)\end{array}$ & $\begin{array}{c}1.118^{* * *} \\
(0.036)\end{array}$ & $\begin{array}{c}1.105^{* * *} \\
(0.036)\end{array}$ \\
\hline cognitive skills & $\begin{array}{l}1.061^{* *} \\
(0.029)\end{array}$ & $\begin{array}{c}1.042 \\
(0.030)\end{array}$ & $\begin{array}{c}1.127^{* * *} \\
(0.033)\end{array}$ & $\begin{array}{l}1.078^{* *} \\
(0.034)\end{array}$ \\
\hline cognitive skills & $0.948^{* *}$ & $0.948^{* *}$ & 0.971 & 0.967 \\
\hline$\times$ social skills & $(0.021)$ & $(0.021)$ & $(0.027)$ & $(0.027)$ \\
\hline O-Levels/ NVQ 2 & & $\begin{array}{l}1.149^{* *} \\
(0.072)\end{array}$ & & $\begin{array}{c}1.247^{* * *} \\
(0.080)\end{array}$ \\
\hline A-Levels/ NVQ 3 & & $\begin{array}{l}1.096 \\
(0.093)\end{array}$ & & $\begin{array}{c}1.577^{* * *} \\
(0.167)\end{array}$ \\
\hline degree/ NVQ 4-6 & & $\begin{array}{c}1.190 \\
(0.140)\end{array}$ & & $\begin{array}{c}1.498^{* * *} \\
(0.167)\end{array}$ \\
\hline married & $\begin{array}{c}1.384^{* * *} \\
(0.161)\end{array}$ & $\begin{array}{c}1.419^{* * *} \\
(0.167)\end{array}$ & $\begin{array}{c}0.676^{* * *} \\
(0.061)\end{array}$ & $\begin{array}{c}0.693^{* * *} \\
(0.063)\end{array}$ \\
\hline parent & $\begin{array}{c}0.665^{* * *} \\
(0.103)\end{array}$ & $\begin{array}{c}0.670^{* * *} \\
(0.104)\end{array}$ & $\begin{array}{c}0.358^{* * *} \\
(0.059)\end{array}$ & $\begin{array}{c}0.380^{* * *} \\
(0.063)\end{array}$ \\
\hline high SES & $\begin{array}{c}1.129 \\
(0.090)\end{array}$ & $\begin{array}{c}1.110 \\
(0.090)\end{array}$ & $\begin{array}{c}1.099 \\
(0.094)\end{array}$ & $\begin{array}{c}1.033 \\
(0.089)\end{array}$ \\
\hline medium SES & $\begin{array}{l}1.141^{* *} \\
(0.064)\end{array}$ & $\begin{array}{l}1.139^{* *} \\
(0.064)\end{array}$ & $\begin{array}{c}1.059 \\
(0.065)\end{array}$ & $\begin{array}{c}1.047 \\
(0.064)\end{array}$ \\
\hline no previous employment & $\begin{array}{c}0.932 \\
(0.057)\end{array}$ & $\begin{array}{l}0.898^{*} \\
(0.059)\end{array}$ & $\begin{array}{c}1.221^{* * *} \\
(0.074)\end{array}$ & $\begin{array}{c}1.090 \\
(0.071)\end{array}$ \\
\hline claimant count rate & $\begin{array}{c}0.788^{* * *} \\
(0.039)\end{array}$ & $\begin{array}{c}0.783^{* * *} \\
(0.039)\end{array}$ & $\begin{array}{c}0.826^{* * *} \\
(0.045)\end{array}$ & $\begin{array}{c}0.811^{* * *} \\
(0.044)\end{array}$ \\
\hline autumn or winter & $\begin{array}{l}0.898^{* *} \\
(0.044)\end{array}$ & $\begin{array}{c}0.898^{* *} \\
(0.044)\end{array}$ & $\begin{array}{c}1.048 \\
(0.055)\end{array}$ & $\begin{array}{c}1.050 \\
(0.055)\end{array}$ \\
\hline number of observations & 2,223 & 2,223 & 2,064 & 2,064 \\
\hline
\end{tabular}

Notes: The table displays hazard ratios and corresponding standard errors in parentheses. Having a father of low SES or not having a male head of household is the base category for father's SES. Missings in the variable on SES were replaced by a zero. A dummy variable indicating this was included in the estimation. Another dummy variable indicating whether there were missings in the information on the qualification level was also included. None of these was significant in the estimations. Further control variables in the estimation are the region of residence, year dummies and the piecewise constant time specification. ${ }^{* * *}$ indicates significance at the $99 \%$ level, ${ }^{* *}$ at the $95 \%$ level and * at the $90 \%$ level. 
for women at the sample mean of cognitive skills. Higher age 7 cognitive skills have a similar effect on the hazard. A one standard deviation increase raises the probability of leaving unemployment by 6.1 percent for men and 12.7 percent for women at the sample mean of social skills. The interaction term of cognitive and social skills at the age of 7 is significantly smaller than one for men, indicating that the two skills are substitutes and can compensate each other to some degree. However, the interaction effect is not significantly different from one for women.

In order to test whether the positive effect of age 7 skills on the hazard is solely due to an increase in the probability of obtaining a higher education, the second and fourth column of Table 2 report results controlling for the level of education. I include indicator variables on having O-Levels/NVQ 2, A-Levels/NVQ 3 or a degree/NVQ 4-6 in the estimation, with having less than O-Levels/NVQ 2 being the reference category. One can see that the hazard ratios for social skills are still highly significant, showing that higher social skills at the age of 7 reduce the duration of unemployment not only via the channel of a higher level of education. Likewise, age 7 cognitive skills increase the probability of finding a job even when controlling for the educational degree. Due to the interaction effect, the hazard ratios presented in the table correspond to the effect of cognitive and social skills at the sample mean of the respective other skill, which is zero by construction. In order to see whether the effect of a one standard deviation increase in skills is relevant at other points of the distribution of the respective other skill, Figure 3 depicts the hazard ratios along the support of the other skill ${ }^{13}$. Moreover, an estimate of the density of the respective other skill gives an impression of the share of individuals that is located at a given point in the support. The graph in the upper right hand corner of Figure 3 shows that cognitive skills significantly increase the hazard rate for men with lower values of social skills, but that the effect is not statistically different from one when social skills are zero or larger. The two lower graphs show the corresponding hazard ratios for women. However, since the interaction term is not statistically different from one, the effect of cognitive and social skills does not differ significantly along the

\footnotetext{
${ }^{13}$ The depicted hazard ratio for cognitive skills, and correspondingly for social skills, is calculated as follows:

hazard ratio $_{\text {cognitive }}=\exp \left\{\beta_{\text {cognitive }}+\operatorname{social} \cdot \beta_{\text {cognitive.social }}\right\}$
} 
support of the respective other skill ${ }^{14}$. Furthermore, the results show that having an educational degree of O-levels/NVQ 2 or more increases the probability of finding a job by 25 to 58 percent for women. For men, only having O-levels/NVQ 2 significantly increases the hazard while the higher qualification levels show positive but insignificant associations with the probability of making a transition to employment.

In duration models, unobserved heterogeneity may lead to biased coefficients even if it is uncorrelated with the covariates at the beginning of the spell (see for example Van den Berg (2001) and Nicoletti and Rondinelli (2010) for a discussion). In order to explore whether the results are subject to this bias, I estimate the model with a normally distributed unobserved heterogeneity term and find almost no change in the estimated coefficients $^{15}$.

Results across all specifications show that the relation between being married at the beginning of the unemployment spell and the duration of the spell differs for men and women. Being married is associated with a significant increase in the hazard rate by about 40 percent for men. Married women, however, have an about 30 percent lower probability of leaving unemployment at any point during the spell. Having children at the beginning of the spell reduces the probability of finding a job for men by about 33 percent and for women by about 62 percent. The father's socio-economic status at the age of 7 is of different relevance for men and women. It is significantly associated with the hazard of leaving unemployment only for men. Having a father of medium as opposed to low SES relates to an increase in the hazard rate by about 13 percent, while the effect of a father of high SES is also positive but not significantly different from zero. In addition, labour market characteristics play a role in explaining the hazard of

\footnotetext{
${ }^{14}$ The proportional hazard rate model assumes that the baseline hazard and the covariates act proportionally on the hazard. This might be violated if some covariates are more important at certain points during the spell than at others. Including interaction terms of the duration and cognitive and social skills in the estimation indicates that cognitive skills might be more relevant in the second half of the first year in unemployment, especially for women. However, the results do not provide statistically robust evidence on a time-varying effect of age 7 cognitive skills, which is why the model without the interaction between cognitive skills and duration is used in the following.

${ }^{15}$ Estimating the model with a Gamma distribution also does not indicate the presence of unobserved heterogeneity, the coefficients converge to almost the same values as in the estimation without frailty. However, the algorithm runs into numerical problems as the variance of the unobserved heterogeneity tends to zero. For men, I find some evidence for unobserved heterogeneity when estimating the model with a discrete frailty distribution with two mass points, but compared to a model without frailty, the estimated coefficients for cognitive and social skills do not change qualitatively. Yet, the estimated coefficients for the baseline hazard differ, pointing out that they should not be interpreted as true duration dependence in the models omitting unobserved heterogeneity. For women, the estimation of the model with a discrete frailty distribution exhibits numerical problems.
} 
leaving unemployment: both for men and for women, a one percentage point increase in the claimant count rate is associated with a decrease in the probability of leaving unemployment by about 20 percent. Results on the other variables that are included in the estimation are reported in Table 3.

In order to interpret the economic significance of the effects of cognitive and social skills one can compare them to the estimated effects of other variables influencing the duration of unemployment. For example, a decrease in the national claimant count rate by one percentage point is associated with an increase in the probability of leaving unemployment by 21 percent for women. This corresponds to a shift of the claimant count rate from the $25^{\text {th }}$ to the $75^{\text {th }}$ percentile in its distribution during the observation period of this study. In order to achieve an equally large increase in the hazard rate by changing social or cognitive skills, one would have to increase a woman's skills by 1.71 standard deviations. This corresponds to moving a woman from the $20^{\text {th }}$ to the $75^{\text {th }}$ percentile in the distribution of social skills. Thus, even though this would imply a sizable shift, the effect of cognitive and social skills in childhood is not to be disregarded for women. For men, the economic conditions are more important for the probability of finding employment than skills in childhood. Achieving the same effect as is associated with a decrease in the claimant count rate by one percentage point would require social skills to increase by more than three standard deviations, which spans almost the entire support of the distribution of social skills. However, due to the significant interaction effect, the required shift decreases for lower values of cognitive skills. Moreover, the importance of early skills relative to educational degrees is not as low for men as when compared to macroeconomic conditions. Yet, comparing the effect of skills to that of educational degrees is problematic. Keeping the latter fixed underestimates the relative importance of early skills since they also increase the probability of achieving a higher education (see e.g. Carneiro et al. (2007)). In addition, measuring a latent concept such as cognitive and social skills is likely to be less precise than measuring the national claimant count rate or an educational degree. The coefficients on cognitive and social skills may therefore underestimate the influence of skills in childhood. 


\subsection{Robustness}

\section{Confounding factors}

This section explores whether the results on the importance of skills in childhood are driven solely by the family or school environment of the child. School characteristics and the family background likely affect both early and later skills. Moreover, the family background might have a direct effect on the probability of finding employment. An association between early skills and the duration of unemployment might therefore arise from a correlation between the school and family background and early and later skills. I address this issue in the previous estimations by controlling for the socio-economic status of the father or male head of household at the age of 7 . Indeed, having a father with a higher SES is positively related to the probability of leaving unemployment, even though this is only significant for men. Yet, this measure might not capture all confounding factors. For this reason, I repeat the estimations including several further control variables measured at the age of 7 and grouped into the categories family background, parenting activities and school characteristics ${ }^{16}$. The results are shown in Table 4. The first column repeats the baseline results from the first and third column in Table 2. Columns 2 to 4 show results from separately adding the different groups of control variables. In the last column, all variables are included at the same time.

The inclusion of further control variables has no large impact on the hazard ratios and significance levels of cognitive and social skills ${ }^{17}$. Therefore, the findings in this section provide some evidence against concerns that the effect of cognitive and social skills at the age of 7 on the duration of unemployment is solely due to confounding factors such as the family background or schooling characteristics.

\section{Heterogeneous effects with respect to education}

Until now, the proportional effect of skills at the age of 7 on the hazard of finding a job is restricted to be the same for all individuals. However, the importance of skills with respect to the probability of leaving unemployment might differ for individuals with different levels of education. They may search for different kinds of jobs for which cognitive and social skills are more or less relevant. Furthermore, it is possible that

\footnotetext{
${ }^{16}$ See Section B in the Appendix for a list of these variables.

${ }^{17}$ When further including control variables that are measured at the age of 11 and 16 , the hazard ratios and corresponding significance levels change only slightly and the qualitative results stay robust.
} 
employers trust higher education to be a signal for higher cognitive and social skills, while putting more effort into evaluating skills of individuals that have a low educational degree. This effect would increase the importance of skills for low educated individuals. In order to explore whether the effect of skills on the probability of finding a job is heterogeneous with respect to education, I estimate the model including interaction terms of skills and the education variables.

The baseline estimation that restricts skills to have a homogeneous effect is reported in the first and the third column of Table 5 for men and women, respectively. Columns 2 and 4 report the hazard ratios of age 7 skills for the different levels of education from the model with interaction terms. Concerning men, cognitive and social skills only have a significant influence on the probability of leaving unemployment for those with an education below O-levels/ NVQ 2. For women, the same result emerges for cognitive skills, while social skills are significant only for those with A-levels or O-levels respectively NVQ 2-3. However, the standard errors of these effects are large and, in most cases, the effects of skills do not vary statistically significantly across educational degrees. In the estimation for women, the effect of cognitive skills slightly differs between those with a degree/ NVQ 4-6 and those with less than O-levels/ NVQ 2 but does not significantly differ between other education levels. In the estimation for men, the effect of social skills differs significantly only between those with O-levels and those with less than O-levels. The hazard ratio on cognitive skills is marginally significantly different only between those with less than O-levels and those who have A-levels or a degree. Given the small sample size in the higher education categories, this exercise can only point to possibly heterogeneous effects of early skills, suggesting that they might be more important for low than for highly educated men in reducing the duration of unemployment. However, a larger sample would be necessary in order to achieve robust statistical evidence on this issue.

\section{Investigating the measure for social skills}

Results until now are based on one specific way of aggregating the information contained in the BSAG, namely defining an overall score. This section presents estimations using two alternative measures for social skills that are also derived from the BSAG. The first alternative disentangles the BSAG into two facets, the second uses the overall score to construct indicators for different categories of social skills. 
For the first alternative, following Ghodsian (1977), and similar to Stott (1974) and Osborne (2000), I construct two scores from the BSAG syndrome scores, labeled "overreact" and "underreact". The score on overreact is the sum of the scores on the syndromes anxiety for acceptance by adults, hostility towards adults, anxiety for acceptance by children, hostility towards children, restlessness and inconsequential behaviour. This factor captures rather aggressive, restless and anxious behaviour (Ghodsian, 1977). The score on underreact is generated by summing the syndrome scores for unforthcomingness, withdrawal, depression and miscellaneous nervous symptoms and represents rather withdrawn and inhibited behaviour ${ }^{18} 19$ (Ghodsian, 1977).

In order to be consistent with the main measure for social skills and to facilitate comparability, I reverse the sign of the resulting scores such that a higher value of overreact and underreact symbolizes higher skills in the respective dimension. Moreover, the scores are normalized to have mean zero and variance one in the sample of all unemployed individuals. The means and standard deviations of the resulting scores are displayed in the upper panel of Table 6 for men and women separately. In both dimensions, girls' social skills at the age of 7 are higher than those of boys.

For the second alternative, I follow Stott (1974) and Davie (1973) in defining three categories for individual's social skills. Those that have an overall BSAG-score of less than 10 are termed stable, those that have a score between 10 and 19 are termed unsettled, and those with a score of 20 or higher are termed maladjusted. The lower panel in Table 6 shows the proportion of individuals in each of the categories for men and women separately. This measure also reflects that, in this sample, women have higher social skills at the age of 7 than men. $71 \%$ of women but only $55 \%$ of men belong to the category stable.

Table 7 shows the hazard ratios from estimations that include the alternative measures for social skills but are otherwise equivalent to the main model as presented in the second

\footnotetext{
${ }^{18}$ The grouping of syndromes emerges from a principal component analysis using the varimax rotation method. When using other rotation methods or when not rotating the factor loadings, other factors might emerge even though they are often similar to the ones used here.

${ }^{19}$ Several studies have related concepts of behaviour and temperament in childhood to the dimensions of the five-factor model in adulthood (see for example Caspi et al. (2003) and John and Srivastava (1999)). Caspi et al. (2003) find that inhibited behaviour at the age of 3, which might be related to the factor underreact measured here, is negatively related to the Big Five factors extraversion and openness to experience and slightly positively related to neuroticism at the age of 26 . Undercontrolled behaviour at the age of 3 , which captures rather impulsive, restless and negative behaviour, and might thus be comparable to "overreact", is found to be negatively related to the scales agreeableness, conscientiousness and openness to experience and positively to neuroticism.
} 
and fourth column of Table 2. One can see in the upper panel that less withdrawn behaviour at the age of 7 significantly increases the probability of leaving unemployment by 8.2 percent for men when cognitive skills are zero. The significant interaction term of cognitive skills and overreact implies that more aggressive behaviour is more harmful for men with low levels of cognitive skills and that higher cognitive skills significantly increase the probability of finding employment for those with a lower overreact score. For women, a one standard deviation increase in underreact is associated with a 7.1 percent higher probability of finding employment. In addition, less aggressive behaviour is associated with a modestly significant increase in the hazard rate by $5.7 \%^{20}$.

The lower panel of Table 7 presents results from estimating the model using the indicator variables for social skills described above. Being stable at the age of 7 is used as the reference category. For men, being unsettled as opposed to stable at the age of 7 has no significant effect on the hazard rate. However, being maladjusted as opposed to stable decreases the hazard rate by $16 \%$ at the overall mean of cognitive skills. This is comparable in magnitude to the effect of having O-levels in contrast to having a lower education. However, the hazard ratio increases and is no longer significantly different from one for high levels of cognitive skills. A one standard deviation increase in cognitive skills significantly increases the probability of finding employment by almost $20 \%$ for individuals that are in the category maladjusted, but is not significantly different for individuals with higher social skills. The results for women follow a similar pattern, but in addition, being unsettled as opposed to stable also significantly decreases the probability of leaving unemployment. These findings suggest that, especially for men, the results on the importance of cognitive and social skills at the age of 7 are driven to a large extent by individuals that are in the lower distribution of childhood social skills.

\section{Do the results change when using skills measured at the age of 11 ?}

According to the hypothesis, when controlling for educational attainment, skills at the age of 7 are important for the duration of the first unemployment spell because they are positively correlated with skills later in life, which in turn influence the duration of

\footnotetext{
${ }^{20}$ Together with the findings on the relation between childhood behaviour and the Big Five, this is in line with the results in Uysal and Pohlmeier (2009), who report a positive association between the probability of finding employment and the scales conscientiousness for men and opennes to experience for women and a negative effect of neuroticism for men.
} 
an unemployment spell. As a further robustness check I therefore explore whether skills measured after the age of 7 are related to the probability of finding a job.

The NCDS also provides measures of cognitive and social skills at the age of 11 . Again, social skills are measured by asking the children's teachers to fill out the BSAG questionnaire. Cognitive skills at the age of 11 are assessed with a math, reading, copying designs and general ability test. In order to be able to compare the results, I use only individuals for whom information on skills at the age of 7 and 11 is available and estimate the model for this sample, once including age 7 skills and once including age 11 skills. The number of observations reduces to 1,893 for men and 1,788 for women, with the mean of cognitive and social skills at the age of 7 being slightly larger in the reduced sample ${ }^{21}$. That is, disproportionately many individuals with lower skills are excluded from the sample, which may attenuate the estimated hazard ratios.

Table 8 presents Pearson correlation coefficients between cognitive and social skills measured at the age of 7 and 11 for women and men separately. The correlation between cognitive skills measured at the age of 7 and 11 is 0.69 both for men and women, which is in line with the finding of a high rank-order stability of cognitive skills early in life (see e.g. Borghans et al. (2008)). Social skills are less correlated between the age of 7 and 11 with a correlation coefficient of 0.34 for men and 0.36 for women. This correlation is somewhat lower than estimates found for various other measures of personality in other studies, but given the time span between the measurements and the assessed measure it is still in a similar range as estimates reported in Roberts and DelVecchio (2000). The reason for the correlation of social skills being lower than that of cognitive skills in this study may be attributed to two factors: First, personality traits are in general found to be less rank-order stable in childhood than cognitive skills (Borghans et al., 2008). Second, the measurement of cognitive skills via tests is less subjective and might therefore be less prone to measurement error than teacher assessments of children's social skills (Borghans et al., 2008).

Table 10 presents estimation results for men in the upper and results for women in the lower panel. Comparing the first and second column, one can see that also social skills at the age of 11 have a positive influence on the probability of finding a job, even though they are no longer statistically significant in the estimation for women. An increase in

\footnotetext{
${ }^{21}$ Note that skills at the age of 7 are standardized in the smaller sample for the estimations.
} 
cognitive skills at the age of 11 is associated with a significant increase in the probability of making a transition to employment for women and, for lower values of social skills, also for men. Moreover, the hazard ratios for cognitive skills at the age of 11 are larger than those for skills at the age of 7 . This is reasonable if age 11 cognitive skills are a better proxy for cognitive skills at the beginning of the unemployment spell than age 7 cognitive skills and, at the same time, cognitive skills in adulthood reduce the duration of unemployment.

Columns 3 and 4 of Table 10 report results using the categories stable, unsettled and maladjusted as measures of social skills ${ }^{22}$. For men in the lower part of the age 11 cognitive skills distribution, both being unsettled and being maladjusted as opposed to stable at the age of 11 significantly decreases the probability of finding employment (see Figure 4). In addition, as found for age 7 cognitive skills, an increase in cognitive skills at the age of 11 significantly increases the hazard rate for individuals that have low social skills. For women, the lower panel of Table 10 and Figure 4 show that being unsettled or maladjusted as opposed to stable at the age of 7 is negatively associated with the hazard rate. Yet, only the coefficient on being unsettled is significantly different from zero at the $90 \%$ confidence level. An increase in cognitive skills significantly increases the hazard rate for women that are in the categories stable or unsettled at the age of 11, but does not seem to have an effect for women in the lowest social skills category.

Summarizing, also higher cognitive and social skills at the age of 11 positively influence the probability of making a transition from unemployment to employment. However, especially for women, the results on social skills are not as statistically significant as those found using measures taken at the age of 7 which points at the need for further research on the channels via which social skills at the age of 7 influence the duration of unemployment ${ }^{23}$.

\footnotetext{
${ }^{22}$ Table 9 displays the share of individuals in the different categories of social skills measured at the age of 7 and 11. $25 \%$ of girls that were maladjusted at the age of 7 are still termed maladjusted at the age of 11 , while $42 \%$ of them are in the category stable. Concerning boys, a larger share, namely $38 \%$, of those who were in the category maladjusted at the age of 7 are still in the category maladjusted at the age of 11 . Moreover, only 142 women are termed maladjusted at the age of 11 .

${ }^{23}$ It could be that social skills at the age of 7 mostly work through increasing later cognitive skills, and once these are controlled for, age 7 social skills are no longer relevant. However, when including skills measured at the age of 7 and at the age of 11 at the same time in the estimation, social skills at the age of 7 are still highly significant.
} 


\section{Conclusion}

This paper studies how social and cognitive skills in childhood are related to the duration of an individual's first unemployment spell in adolescence and early adulthood by estimating a flexible proportional hazard rate model.

The results show that higher cognitive and social skills at the age of 7 are associated with an increased probability of finding employment. For men, cognitive and social skills are only relevant for individuals in the lower part of the distribution of the respective other skill. That is, those with below average social skills benefit from an increase in cognitive skills and vice versa. Correspondingly, the effect of social skills seems to be driven by those in the lowest social skills category at the age of 7 for men. For women, the negative interaction effect is less pronounced. Adding education to the estimation slightly reduces the estimated hazard ratios but leaves the qualitative results unchanged. Moreover, the estimates are robust to controlling for parenting activities, family background and school characteristics at the age of 7 . In addition, also skills measured at the age of 11 are related to the probability of finding employment. However, the point estimates for social skills are smaller and of lower statistical significance when using skills measured at the later age. These results speak in favour of the hypothesis that the importance of cognitive skills at the age of 7 for the probability of finding employment is due to the importance of later skills. However, at the same time they point at the need for more evidence on the channels via which early social skills are related to the duration of an unemployment spell.

The estimates suggest that the economic significance of the effect of cognitive and social skills at the age of 7 is comparable to that of the national claimant count rate at the beginning of the unemployment spell for women. For men, the relative importance seems to be considerably smaller. However, since measuring skills is likely to be less precise than measuring a conventional economic variable such as the claimant count rate, the relative importance of skills may be underestimated.

The results of this study offer more insights into the finding of Gregg (2001) by showing that the reduced number of months spent in unemployment due to an increase in social skills is at least partly also due to a reduction in the length of an unemployment spell. Moreover, the results add to the literature on the relation between the duration of unemployment spells and cognitive and noncognitive skills (Uhlendorff, 2004; 
Lindqvist and Vestman, 2010; Uysal and Pohlmeier, 2009; DellaVigna and Paserman, 2005) by providing evidence on the importance of skills in childhood, controlling for two dimensions of skills and analysing the effect both for men and women. Even though the positive association between early skills and the length of an unemployment spell is not established using exogenous variation, controlling for a large range of background factors does not change the results. This suggests that policy measures aiming at increasing early cognitive and social skills contribute also to reducing the risk of long unemployment episodes. Moreover, in light of recent debates on achievements in international pupil tests that often focus on cognitive skills, this study provides additional evidence showing that one should not neglect investing in children's social skills since they are related to later outcomes in a similar way as cognitive skills.

A limitation of this study is that the evidence builds on the experience of one specific cohort in their early years on the labour market. Future research should therefore gather more evidence on the relationship between cognitive and social skills and the duration of unemployment, using different cohorts and measuring skills at different points in the lifecycle.

\section{References}

Achenbach, T., McConaughy, S., and Howell, C. (1987). Child/ adolescent behavioral and emotional problems: Implications of cross-informant correlations for situational specificity. Psychological Bulletin, 101:213-232.

Arulampalam, W. and Stewart, M. B. (1995). The determinants of individual unemployment durations in an era of high unemployment. Economic Journal, 105(429):321-332.

Blomeyer, D., Coneus, K., Laucht, M., and Pfeiffer, F. (2009). Initial risk matrix, home resources, ability development and children's achievement. Journal of the European Economic Association, 7(2-3):638-648.

Borghans, L., Duckworth, A. L., Heckman, J., and ter Weel, B. (2008). The economics and psychology of personality traits. Journal of Human Resources, 43(4):972-1059.

Bowles, S., Gintis, H., and Osborne, M. (2001). Incentive-enhancing preferences: Personality, behavior, and earnings. American Economic Review, 91(2):155-158. 
Bynner, J. (2005). NCDS 5: Derived Variables 1, pages 30-34. Centre for Longitudinal Studies.

Cahuc, P. and Zylberberg, A. (2004). Labor Economics. MIT Press Books. The MIT Press.

Carneiro, P., Crawford, C., and Goodman, A. (2007). The impact of early cognitive and non-cognitive skills on later outcomes. CEE Discussion Paper 0092.

Carneiro, P., Crawford, C., and Goodman, A. (2008). The impact of early cognitive and non-cognitive skills on later outcomes. Mimeo.

Caspi, A., Harrington, H., Milne, B., Amell, J. W., Theodore, R. F., and Moffitt, T. E. (2003). Children's behavioral styles at age 3 are linked to their adult personality traits at age 26. Journal of Personality, 71(4):495-514.

Caspi, A., Wright, B., Moffitt, T., and Silva, P. (1998). Early failure in the labor market: Childhood and adolescent predictors of unemployment in the transition to adulthood. American Sociological Review, 63(3):424-451.

Centre for Longitudinal Studies (2005). NCDS1 (1965) - Guide to the Dataset.

Clasen, J. (1994). Paying the Jobless. Avebury, Aldershot.

Costa, P. T. and McCrae, R. R. (1992). Four ways five factors are basic. Personality and Individual Differences, 13(6):653-665.

Cunha, F. and Heckman, J. (2007). The technology of skill formation. The American Economic Review, 97(2):31-47.

Cunha, F., Heckman, J., Lochner, L., and Masterov, D. (2006). Interpreting the evidence on life cycle skill formation. volume 1 of Handbook of the Economics of Education, chapter 12, pages 697-812. Elsevier.

Currie, J. and Thomas, D. (2001). Early test scores, socioeconomic status, school quality and future outcomes. In Worker Wellbeing in a Changing Labor Market, volume 20 of Research in Labor Economics, pages 103-132. Elsevier.

Davie, R. (1973). The behavior and adjustment in school of seven-year-olds: Sex and social class differences. Early Child Development and Care, 2:39-48. 
DellaVigna, S. and Paserman, M. D. (2005). Job search and impatience. Journal of Labor Economics, 23(3):527-588.

Dennissen, J. J. A., Asendorpf, J. B., and van Aken, M. A. G. (2008). Childhood personality predicts long-term trajectories of shyness and aggressiveness in the context of demographic transitions in emerging adulthood. Journal of Personality, 76(1):67100.

Devine, T. J. and Kiefer, N. M. (1991). Empirical Labor Economics: The Search Approach. Oxford University Press, New York and Oxford.

Feinstein, L. (2000). The relative economic importance of academic, psychological and behavioural attributes developed in childhood. CEP Discussion Paper 443.

Ghodsian, M. (1977). Children's behaviour and the BSAG: Some theoretical and statistical considerations. British Journal of Social and Clinical Psychology, 16:23-28.

Goldsmith, A., Veum, J., and Darity, W. J. (1995). Are being unemployed and being out of the labor force distinct states? A psychological approach. Journal of Economic Psychology, 16(2):275-295.

Goodenough, F. (1926). Measurement of Intelligence by Drawings. World Book Company.

Gregg, P. (2001). The impact of youth unemployment on adult unemployment in the NCDS. The Economic Journal, 111:F626-F653.

Gregg, P. and Machin, S. (2000). Child development and success or failure in the youth labor market. In Youth Employment and Joblessness in Advanced Countries, NBER Chapters, pages 247-288. National Bureau of Economic Research, Inc.

Heckman, J. (2008). Schools, skills and synapses. Economic Inquiry, 46(3):289-324.

Heckman, J., Stixrud, J., and Urzua, S. (2006). The effects of cognitive and noncognitive abilities on labor market outcomes and social behavior. Journal of Labor Economics, 24(3):411-482.

Hobcraft, J. (1998). Intergenerational and life-course transmission of social exclusion: Influences of childhood poverty, family disruption, and contact with the police. CASE Papers, 15. 
Hobcraft, J. (2000). The roles of schooling and educational qualifications in the emergence of adult social exclusion. CASE Papers, 43.

Jenkins, S. (1995). Easy estimation methods for discrete-time duration models. Oxford Bulletin of Economics and Statistics, 57(1):129-138.

John, O. P. and Srivastava, S. (1999). The big five trait taxonomy: History, measurement and theoretical perspectives. In Pervin, L. A. and John, O. P., editors, Handbook of Personality: Theory and Research, pages 102-138. Guilford Press, New York.

Jones, M. P. (1996). Indicator and stratification methods for missing explanatory variables in multiple linear regression. Journal of the American Statistical Association, 91(433):222-230.

Kiefer, N. M. (1985). Evidence on the role of education in labor turnover. The Journal of Human Resources, 20(3):445-452.

Lindqvist, E. and Vestman, R. (2010). The labor market returns to cognitive and noncognitive ability: Evidence from the Swedish enlistment. American Economic Journal: Applied Economics. Forthcoming.

Mittelstädt, A. and Veil, E. (1975). Unemployment benefits and related payments in seven major countries. OECD economic outlook: Occasional studies.

Mortensen, D. T. (1986). Job search and labor market analysis. In Ashenfelter, O. and Layard, R., editors, Handbook of Labor Economics, volume 2 of Handbook of Labor Economics, chapter 15, pages 849-919. Elsevier.

Narendranathan, W. and Stewart, M. B. (1993). Modelling the probability of leaving unemployment: Competing risks models with flexible baseline hazards. Journal of the Royal Statistical Society: Series C, 42(1):63-83.

Nickell, S. (1979). Education and liftime patterns of unemployment. The Journal of Political Economy, 87(S5):S117-S131.

Nicoletti, C. and Rondinelli, C. (2010). The (mis)specification of discrete duration models with unobserved heterogeneity: A monte carlo study. Journal of Econometrics, 159:1-13. 
Osborne, M. (2000). The power of personality: Labor market rewards and the transmission of earnings. Electronic Doctoral Dissertations for UMass Amherst. Paper AAI9988828.

Prentice, R. L. and Gloeckler, L. A. (1978). Regression analysis of grouped survival data with application to breast cancer data. Biometrics, 34(1):57-67.

Pringle, M. K., Butler, N., and Davie, R. (1966). 11,000 Seven-Year-Olds. Longman, in association with National Children's Bureau.

Roberts, B. W. and DelVecchio, W. F. (2000). The rank-order consistency of personality traits from childhood to old age: A quantitative review of longitudinal studies. Psychological Bulletin, 126(1):3-25.

Southgate, V. (1962). Southgate Group Reading Tests: Manual of Instructions. University of London Press.

Stott, D. H. (1974). The Social Adjustment of Children - Manual of the Bristol SocialAdjustment Guides. University of London Press, London, 5 edition.

Uhlendorff, A. (2004). Der Einfluss von Persönlichkeitseigenschaften und sozialen Ressourcen auf die Dauer von Arbeitslosigkeit. Kölner Zeitschrift für Soziologie und Sozialpsychologie, 56:279-303.

University of London. Institute of Education. Centre for Longitudinal Studies (2008a). National Child Development Study: Childhood Data, Sweeps 0-3, 1958-1974 [computer file]. 2nd edition. National Birthday Trust Fund, National Children's Bureau, [original data producer(s)]. Colchester, Essex: UK Data Archive [distributor]. SN: 5565.

University of London. Institute of Education. Centre for Longitudinal Studies (2008b). National Child Development Study: Sweep 4, 1981, and Public Examination Results, 1978 [computer file]. 2nd edition. National Children's Bureau, [original data producer(s)]. Colchester, Essex: UK Data Archive [distributor]. SN: 5566.

University of London. Institute of Education. Centre for Longitudinal Studies (2008c). National Child Development Study: Sweep 5, 1991 [computer file]. 2nd edition. City University. Social Statistics Research Unit, [original data producer(s)]. Colchester, Essex: UK Data Archive [distributor]. SN: 5567. 
Uysal, S. D. and Pohlmeier, W. (2009). Unemployment duration and noncognitive skills. Unpublished Paper, University of Konstanz.

Van den Berg, G. J. (1994). The effects of changes of the job offer arrival rate on the duration of unemployment. Journal of Labor Economics, 12(3):478-498.

Van den Berg, G. J. (2001). Duration models: Specification, identification and multiple durations. In Heckman, J. and Leamer, E., editors, Handbook of Econometrics, volume 5, chapter 55, pages 3381-3460. Elsevier. 


\section{Appendix}

\section{A. Construction of Dataset}

Using the information on education provided in NCDS 4, I derive an individual's qualification at the beginning of the unemployment spell. There are several questions asking the individuals about qualifications obtained during training courses, apprenticeships, or any other education since leaving school. I aggregate the different qualifications according to the description in the guide accompanying the documentation for NCDS 5 "NCDS5 - Derived Variables 1" (Bynner, 2005). Following this, qualifications are grouped into 6 categories: no qualifications, CSE 2-5/ equivalent NVQ $1^{24}$, O-Level/ equivalent NVQ 2, A-Level/ equivalent NVQ 3, higher qualification/ equivalent NVQ 4 and degree/ higher NVQ 5 and NVQ 6. In the empirical analysis I further aggregate these categories and form the following groups of highest achieved qualifications: below O-Levels/ NVQ 0-1, O-Levels/ NVQ 2, A-Levels/ NVQ3 and higher qualification or degree/ NVQ 4-6. I construct the complete qualification biography for each individual by recording at which point in time she received a qualification. Whenever it is not possible to determine the exact date, I assign the lower qualification level until the higher one is certainly obtained. I include a dummy in the estimation, indicating whether or not the complete qualification history could be constructed in this way in order to control for a potential structural pattern of incompleteness. The coefficients on this dummy are almost never significantly different from zero.

In order to control for family status, I record for each cohort member whether she is married or not and has children or not at each point in time, using information on marital status and biological children which was collected in NCDS 4. Additionally, I control for the cohort member's family background during her own childhood. The social class of the father or male head of the household is reported in the form of an index in $\operatorname{NCDS} 1^{25}$. In order to generate a measure of socio-economic background I group the social class categories according to the following rule: I assign a high socio-economic status (SES) if the father belongs to social class I or II, a medium SES if the father

\footnotetext{
${ }^{24}$ NVQ stands for National Vocational Qualification level.

${ }^{25}$ Information on the employment and occupational status according to the General Register Office (GRO) 1960 classification was used to construct this index.
} 
belongs to social class III and a low SES if the father belongs to social class IV or V. I also create a category for not having a male head of household.

In case information on a variable is missing, I assign a value and create a dummy variable that indicates this. This indicator is included in the estimation in order to control for potential selectivity in missings. This makes it unnecessary to drop an individual because of missing information on one control variable ${ }^{26}$. In case of missing information in a dummy variable I replace the missing with zero. Missings in continuous variables are replaced with the mean and missings in discrete variables are replaced with the median.

In order to control for regional variation in macroeconomic conditions, I include the latest information on the region of residence. This is the region that the cohort members report in NCDS 3, which is at the age of 16. If this is unknown, I use the information provided in NCDS 2. The monthly claimant count rates for Great Britain are taken from the website of the Office for National Statistics.

\section{B. List of Covariates}

The following control variables, reported at the age of 7 , are additionally included in the estimation in Table 4.

- family background:

socio-economic status of father or male head of household; whether the child was an only child; number of household members; birth order; whether mother stayed on at school after the minimum school leaving age; father's years of education; mother's and her husband's age at childbirth; whether the father reads a lot of books; whether the mother reads a lot of books; whether the mother speaks mostly English with the child; whether the family has any difficulties as assessed by the health visitor ${ }^{27}$

- parenting activities:

\footnotetext{
${ }^{26}$ For a discussion of the treatment of missing information in a linear estimation framework see Jones (1996).

${ }^{27}$ Including difficulties in the following areas: housing, financial, physical illness or disability, mental illness or neurosis, mental subnormality, death of child's father, death of child's mother, divorce, separation or desertion, domestic tension, "in-law" conflicts, unemployment and alcoholism.
} 
whether the parents would like the child to stay on at school after the minimum school leaving age; whether the mother reads to/ with the child; whether the father reads to/ with the child; whether the father takes the child outside; whether the father takes an active role in raising the child as seen by the mother; whether the mother started working before the child started school; whether the mother started working after the child started school; whether the mother shows interest in the child's education as seen by the teacher; whether the father shows interest in the child's education as seen by the teacher; whether the parents have actively sought to discuss the child with the teacher in school

- school characteristics:

whether the child is at an infant as opposed to a junior school or other type of school; number of pupils in the child's class; whether the school has a parent/teacher association; whether the school arranges meetings with the parents on educational matters; whether the school organizes any social functions for parents; whether parents provide substantial help in money, kind or labour to the school

\section{Who experiences unemployment before the age of 23 ?}

This paper analyses the duration of an unemployment spell for individuals who became unemployed for more than two weeks at least once between the age of 16 and 23. Those who did not become unemployed during this time have no observations on the outcome variable and are therefore not included in the sample used in the estimations. Nevertheless, it is likely that the probability of becoming unemployed and being in the sample is not random. This section therefore explores which factors increase the likelihood of being in the sample used for the duration analysis.

Table 11 contrasts the mean and standard deviation of explanatory variables for those who have experienced unemployment and those who have not. Average skills at the age of 7 are higher among those who were not unemployed before the age of 23 than among those who experienced unemployment. The latter have an average score of cognitive skills of -0.09 and average social skills of -0.11 . The corresponding figures for those who were not unemployed are 0.07 for cognitive skills and 0.08 for social skills. Hence, there is a difference of about 16 to 19 percent of a standard deviation between the two 
groups, indicating that these skills are related to an increased probability of becoming unemployed before the age of 23. Furthermore, among those who were not unemployed before the age of 23 , the percentage of individuals who stayed on at school after the age of 16 is slightly higher, with $29 \%$ as opposed to $26 \%$.

Table 12 presents results from a probit estimation of the probability of experiencing unemployment until the age of $23^{28}$. This exercise further explores the composition of individuals that are in the sample for the analysis of the duration of the first unemployment spell. Columns 1 and 2 refer to estimations for men, 3 and 4 to those for women. Specification (a) includes skills at the age of 7 , whether the individual stayed on at school after the age of 16, father's socioeconomic status and region of residence at the age of 16 as right-hand side variables. The impression from the descriptive statistics is partly confirmed in this estimation. Higher cognitive and social skills are significantly associated with a reduced probability of becoming unemployed. Having stayed on at school after the age of 16 , which serves as a proxy for educational attainment, is positively but not significantly correlated with the probability of becoming unemployed. However, the effect of having stayed on at school is hard to interpret. Staying on at school after the age of 16 also reduces the time at risk of becoming unemployed until the age of 23 and implies that individuals entered the labour market in a different year and possibly different economic environment ${ }^{29}$. A higher SES of the father is only significantly negatively related to the probability of becoming unemployed for men. Specification (b) additionally controls for information on the family background, parenting activities and school characteristics ${ }^{30}$. This decreases the average partial effect of cognitive skills, which is no longer significantly different from zero. However, a one standard deviation increase in social skills is still associated with a significant decrease of 3.4 (2.0) percentage points in the probability of becoming unemployed, and thus in the probability of being in the sample for the duration analysis, for men (women).

\footnotetext{
${ }^{28}$ Note that Hobcraft (1998) has done a similar analysis with the NCDS, examining the probability of ever becoming unemployed until the age of 33 for men. He finds that cognitive and social skills in childhood are related to educational achievement, but not directly to the probability of experiencing unemployment until the age of 33 .

${ }^{29}$ The claimant count rate in Great Britain slightly increased from 1974 onwards, which is the year when cohort members turned 16 and finished compulsory education.

${ }^{30} \mathrm{~A}$ detailed list of the included variables can be found in Appendix B.
} 


\section{Tables and Figures}

Figure 1: Kernel density estimates of the distributions of skills at the age of 7
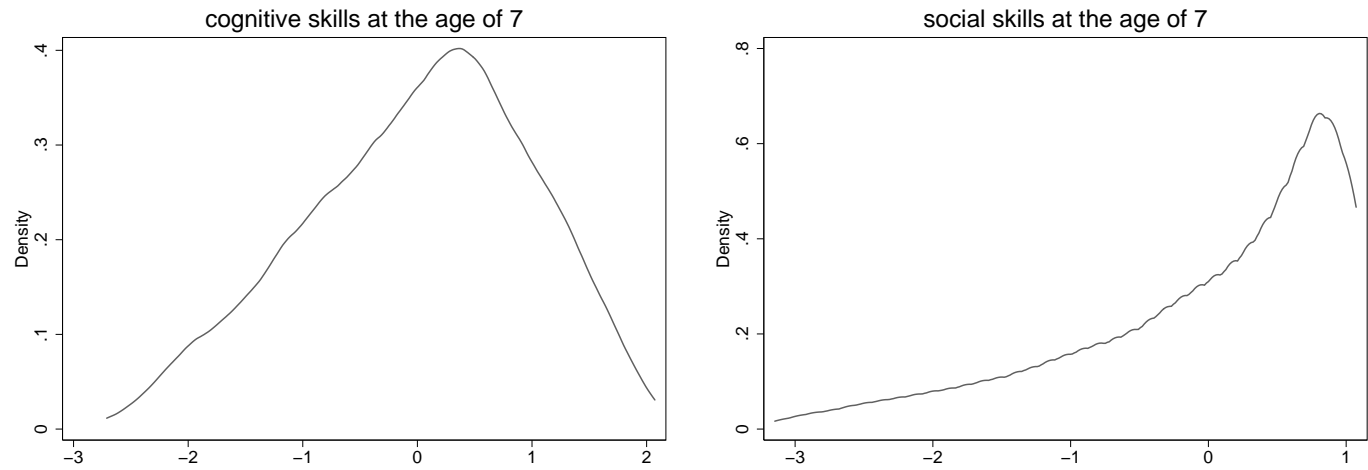

Figure 2: Kaplan-Meier estimates of survival functions for above and below average cognitive respectively social skills
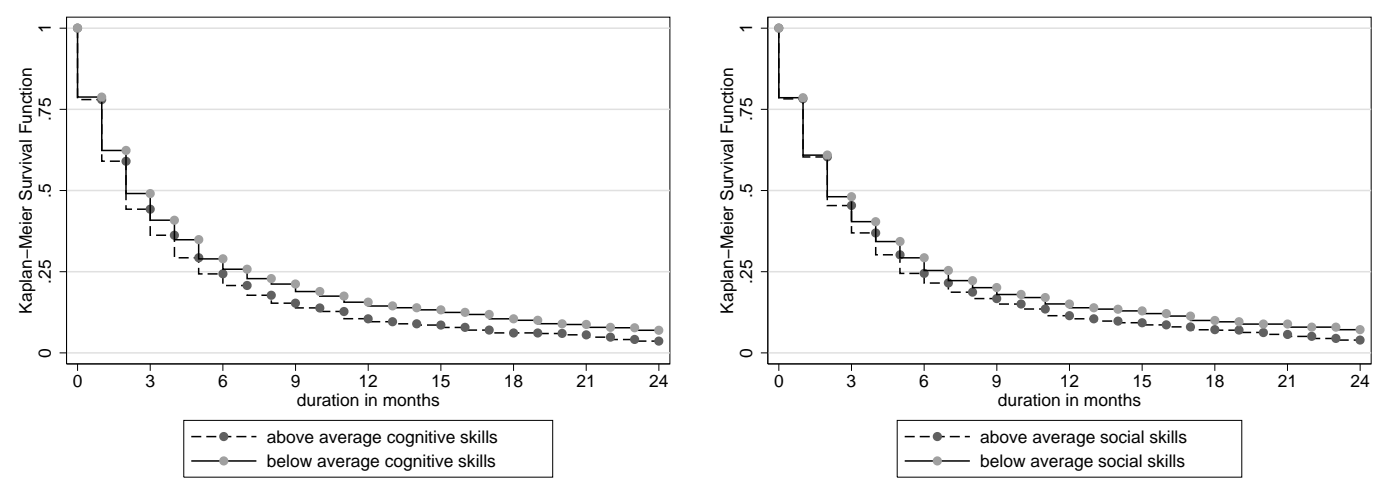
Table 3: Estimation results of duration model - continued from Table 2

\begin{tabular}{|c|c|c|c|c|}
\hline & \multicolumn{2}{|c|}{ men } & \multicolumn{2}{|c|}{ women } \\
\hline & $\begin{array}{c}\text { without } \\
\text { education }\end{array}$ & $\begin{array}{c}\text { with } \\
\text { education }\end{array}$ & $\begin{array}{l}\text { without } \\
\text { education }\end{array}$ & $\begin{array}{c}\text { with } \\
\text { education }\end{array}$ \\
\hline constant & $\begin{array}{l}0.673^{* *} \\
(0.112)\end{array}$ & $\begin{array}{l}0.684^{* *} \\
(0.114)\end{array}$ & $\begin{array}{c}0.369^{* * *} \\
(0.067)\end{array}$ & $\begin{array}{c}0.385^{* * *} \\
(0.071)\end{array}$ \\
\hline \multicolumn{5}{|c|}{ piecewise constant baseline specification } \\
\hline month 2 & $\begin{array}{l}1.090 \\
(0.074)\end{array}$ & $\begin{array}{c}1.093 \\
(0.074)\end{array}$ & $\begin{array}{c}1.191^{* *} \\
(0.087)\end{array}$ & $\begin{array}{c}1.200^{* *} \\
(0.087)\end{array}$ \\
\hline month 3 & $\begin{array}{c}1.225^{* * *} \\
(0.091)\end{array}$ & $\begin{array}{c}1.231^{* * *} \\
(0.091)\end{array}$ & $\begin{array}{c}1.250^{* * *} \\
(0.100)\end{array}$ & $\begin{array}{c}1.268^{* * * *} \\
(0.102)\end{array}$ \\
\hline month 4 & $\begin{array}{c}0.916 \\
(0.085)\end{array}$ & $\begin{array}{c}0.922 \\
(0.086)\end{array}$ & $\begin{array}{c}0.968 \\
(0.095)\end{array}$ & $\begin{array}{c}0.990 \\
(0.097)\end{array}$ \\
\hline month 5 & $\begin{array}{c}1.010 \\
(0.102)\end{array}$ & $\begin{array}{c}1.019 \\
(0.103)\end{array}$ & $\begin{array}{c}0.880 \\
(0.099)\end{array}$ & $\begin{array}{c}0.908 \\
(0.102)\end{array}$ \\
\hline month 6 & $\begin{array}{c}1.027 \\
(0.117)\end{array}$ & $\begin{array}{c}1.038 \\
(0.118)\end{array}$ & $\begin{array}{l}1.005 \\
(0.121)\end{array}$ & $\begin{array}{c}1.048 \\
(0.127)\end{array}$ \\
\hline month 7 & $\begin{array}{l}0.765^{*} \\
(0.111)\end{array}$ & $\begin{array}{l}0.774^{*} \\
(0.112)\end{array}$ & $\begin{array}{c}0.787 \\
(0.116)\end{array}$ & $\begin{array}{c}0.824 \\
(0.122)\end{array}$ \\
\hline month 8 & $\begin{array}{c}0.839 \\
(0.128)\end{array}$ & $\begin{array}{c}0.851 \\
(0.130)\end{array}$ & $\begin{array}{l}0.761^{*} \\
(0.125)\end{array}$ & $\begin{array}{c}0.800 \\
(0.132)\end{array}$ \\
\hline month 9 & $\begin{array}{c}0.622^{* *} \\
(0.118)\end{array}$ & $\begin{array}{c}0.632^{* *} \\
(0.120)\end{array}$ & $\begin{array}{c}0.663^{* *} \\
(0.127)\end{array}$ & $\begin{array}{l}0.701^{*} \\
(0.134)\end{array}$ \\
\hline month 10 & $\begin{array}{c}0.529^{* * *} \\
(0.116)\end{array}$ & $\begin{array}{c}0.539^{* * *} \\
(0.118)\end{array}$ & $\begin{array}{c}0.802 \\
(0.153)\end{array}$ & $\begin{array}{c}0.851 \\
(0.163)\end{array}$ \\
\hline month 11 & $\begin{array}{c}0.457^{* * *} \\
(0.117)\end{array}$ & $\begin{array}{c}0.466^{* * *} \\
(0.119)\end{array}$ & $\begin{array}{c}0.540^{* *} \\
(0.135)\end{array}$ & $\begin{array}{c}0.581^{* *} \\
(0.145)\end{array}$ \\
\hline month 12 & $\begin{array}{c}0.834 \\
(0.176)\end{array}$ & $\begin{array}{c}0.852 \\
(0.181)\end{array}$ & $\begin{array}{l}1.026 \\
(0.206)\end{array}$ & $\begin{array}{l}1.114 \\
(0.225)\end{array}$ \\
\hline months $13-24$ & $\begin{array}{c}0.414^{* * *} \\
(0.057)\end{array}$ & $\begin{array}{c}0.427^{* * *} \\
(0.059)\end{array}$ & $\begin{array}{c}0.500^{* * *} \\
(0.070)\end{array}$ & $\begin{array}{c}0.546^{* * * *} \\
(0.077)\end{array}$ \\
\hline \multicolumn{5}{|l|}{ year dummies } \\
\hline 1975 & $\begin{array}{c}0.933 \\
(0.104)\end{array}$ & $\begin{array}{c}0.901 \\
(0.101)\end{array}$ & $\begin{array}{l}0.813^{*} \\
(0.097)\end{array}$ & $\begin{array}{c}0.770^{* *} \\
(0.092)\end{array}$ \\
\hline 1976 & $\begin{array}{c}1.079 \\
(0.176)\end{array}$ & $\begin{array}{c}1.044 \\
(0.172)\end{array}$ & $\begin{array}{c}0.941 \\
(0.163)\end{array}$ & $\begin{array}{c}0.855 \\
(0.150)\end{array}$ \\
\hline 1977 & $\begin{array}{c}1.208 \\
(0.220)\end{array}$ & $\begin{array}{c}1.168 \\
(0.216)\end{array}$ & $\begin{array}{c}0.948 \\
(0.188)\end{array}$ & $\begin{array}{c}0.841 \\
(0.168)\end{array}$ \\
\hline 1978 & $\begin{array}{c}1.180 \\
(0.215)\end{array}$ & $\begin{array}{c}1.126 \\
(0.208)\end{array}$ & $\begin{array}{c}0.924 \\
(0.182)\end{array}$ & $\begin{array}{c}0.824 \\
(0.164)\end{array}$ \\
\hline 1979 & $\begin{array}{c}1.065 \\
(0.166)\end{array}$ & $\begin{array}{c}0.986 \\
(0.161)\end{array}$ & $\begin{array}{c}0.691^{* *} \\
(0.117)\end{array}$ & $\begin{array}{c}0.591^{* * *} \\
(0.104)\end{array}$ \\
\hline 1980 & $\begin{array}{c}0.895 \\
(0.186)\end{array}$ & $\begin{array}{c}0.833 \\
(0.178)\end{array}$ & $\begin{array}{c}0.920 \\
(0.204)\end{array}$ & $\begin{array}{c}0.786 \\
(0.178)\end{array}$ \\
\hline 1981 & $\begin{array}{l}1.155 \\
(0.390)\end{array}$ & $\begin{array}{l}1.086 \\
(0.369)\end{array}$ & $\begin{array}{c}1.269 \\
(0.468)\end{array}$ & $\begin{array}{l}1.138 \\
(0.423)\end{array}$ \\
\hline \multicolumn{5}{|c|}{ region at the age of 16 dummies } \\
\hline North & $\begin{array}{c}0.920 \\
(0.110)\end{array}$ & $\begin{array}{c}0.912 \\
(0.109)\end{array}$ & $\begin{array}{c}1.137 \\
(0.146)\end{array}$ & $\begin{array}{c}1.152 \\
(0.148)\end{array}$ \\
\hline North West & $\begin{array}{l}1.006 \\
(0.110)\end{array}$ & $\begin{array}{c}0.996 \\
(0.110)\end{array}$ & $\begin{array}{c}1.579^{* * *} \\
(0.187)\end{array}$ & $\begin{array}{c}1.569^{* * *} \\
(0.186)\end{array}$ \\
\hline E \& W.Riding & $\begin{array}{l}1.127 \\
(0.138)\end{array}$ & $\begin{array}{l}1.114 \\
(0.136)\end{array}$ & $\begin{array}{c}1.407^{* * * *} \\
(0.183)\end{array}$ & $\begin{array}{c}1.436^{* * *} \\
(0.187)\end{array}$ \\
\hline North Midlands & $\begin{array}{c}1.367^{* *} \\
(0.175)\end{array}$ & $\begin{array}{c}1.340^{* *} \\
(0.173)\end{array}$ & $\begin{array}{c}1.908^{* * *} \\
(0.258)\end{array}$ & $\begin{array}{c}1.883^{* * * *} \\
(0.255)\end{array}$ \\
\hline Midlands & $\begin{array}{l}1.086 \\
(0.128)\end{array}$ & $\begin{array}{l}1.072 \\
(0.126)\end{array}$ & $\begin{array}{l}1.291^{* *} \\
(0.163)\end{array}$ & $\begin{array}{l}1.278^{*} \\
(0.162)\end{array}$ \\
\hline East & $\begin{array}{c}1.284^{* *} \\
(0.158)\end{array}$ & $\begin{array}{c}1.274^{* *} \\
(0.157)\end{array}$ & $\begin{array}{c}1.788^{* * *} \\
(0.247)\end{array}$ & $\begin{array}{c}1.808^{* * *} \\
(0.250)\end{array}$ \\
\hline South East & $\begin{array}{l}1.312^{* *} \\
(0.146)\end{array}$ & $\begin{array}{l}1.299^{* *} \\
(0.145)\end{array}$ & $\begin{array}{c}1.701^{* * *} \\
(0.211)\end{array}$ & $\begin{array}{c}1.655^{* * *} \\
(0.205)\end{array}$ \\
\hline South & $\begin{array}{c}1.441^{* * *} \\
(0.200)\end{array}$ & $\begin{array}{c}1.433^{* * *} \\
(0.200)\end{array}$ & $\begin{array}{c}1.724^{* * *} \\
(0.243)\end{array}$ & $\begin{array}{c}1.718^{* * *} \\
(0.243)\end{array}$ \\
\hline South West & $\begin{array}{c}0.986 \\
(0.130)\end{array}$ & $\begin{array}{c}0.968 \\
(0.128)\end{array}$ & $\begin{array}{c}1.606^{* * *} \\
(0.229)\end{array}$ & $\begin{array}{c}1.599^{* * *} \\
(0.229)\end{array}$ \\
\hline Scotland & $\begin{array}{c}0.930 \\
(0.107)\end{array}$ & $\begin{array}{c}0.911 \\
(0.105)\end{array}$ & $\begin{array}{l}1.255^{*} \\
(0.157)\end{array}$ & $\begin{array}{l}1.188 \\
(0.150)\end{array}$ \\
\hline missing indicator & & & & \\
\hline $\begin{array}{l}\text { info on region at the age of } 16 \\
\text { missing }\end{array}$ & $\begin{array}{c}0.963 \\
(0.087)\end{array}$ & $\begin{array}{c}0.964 \\
(0.087)\end{array}$ & $\begin{array}{r}0.822^{* *} \\
(0.077)\end{array}$ & $\begin{array}{c}0.812^{* *} \\
(0.077)\end{array}$ \\
\hline SES missing & $\begin{array}{c}0.856 \\
(0.095)\end{array}$ & $\begin{array}{c}0.855 \\
(0.096)\end{array}$ & $\begin{array}{c}0.951 \\
(0.118)\end{array}$ & $\begin{array}{c}0.946 \\
(0.117)\end{array}$ \\
\hline no exact education & & 1.125 & & 1.261 \\
\hline history & & $(0.173)$ & & $(0.198)$ \\
\hline number of observations & 2223 & 2223 & 2064 & 2064 \\
\hline
\end{tabular}


Table 4: Controlling for different sets of covariates at the age of 7

\begin{tabular}{|c|c|c|c|c|c|}
\hline & (1) & $(2)$ & $(3)$ & $(4)$ & $(5)$ \\
\hline \multicolumn{6}{|l|}{ men $(\mathrm{N}=2223)$} \\
\hline social skills & $\begin{array}{l}1.060^{* *} \\
(0.028)\end{array}$ & $\begin{array}{l}1.053^{*} \\
(0.028)\end{array}$ & $\begin{array}{l}1.050^{*} \\
(0.028)\end{array}$ & $\begin{array}{l}1.061^{* *} \\
(0.028)\end{array}$ & $\begin{array}{l}1.049^{*} \\
(0.028)\end{array}$ \\
\hline cognitive skills & $\begin{array}{c}1.042 \\
(0.030)\end{array}$ & $\begin{array}{c}1.045 \\
(0.030)\end{array}$ & $\begin{array}{c}1.038 \\
(0.030)\end{array}$ & $\begin{array}{l}1.045 \\
(0.030)\end{array}$ & $\begin{array}{c}1.047 \\
(0.031)\end{array}$ \\
\hline $\begin{array}{l}\text { cognitive skills } \\
\times \text { social skills }\end{array}$ & $\begin{array}{l}0.948^{* *} \\
(0.021)\end{array}$ & $\begin{array}{l}0.947^{* *} \\
(0.022)\end{array}$ & $\begin{array}{l}0.954^{* *} \\
(0.022)\end{array}$ & $\begin{array}{l}0.947^{* *} \\
(0.022)\end{array}$ & $\begin{array}{l}0.949^{* *} \\
(0.022)\end{array}$ \\
\hline O-Levels/ NVQ 2 & $\begin{array}{l}1.149^{* *} \\
(0.072)\end{array}$ & $\begin{array}{c}1.106 \\
(0.071)\end{array}$ & $\begin{array}{l}1.119^{*} \\
(0.071)\end{array}$ & $\begin{array}{l}1.147^{* *} \\
(0.072)\end{array}$ & $\begin{array}{c}1.093 \\
(0.071)\end{array}$ \\
\hline A-Levels/ NVQ 3 & $\begin{array}{c}1.096 \\
(0.093)\end{array}$ & $\begin{array}{c}1.083 \\
(0.094)\end{array}$ & $\begin{array}{c}1.076 \\
(0.093)\end{array}$ & $\begin{array}{c}1.093 \\
(0.093)\end{array}$ & $\begin{array}{c}1.076 \\
(0.095)\end{array}$ \\
\hline degree/ NVQ 4-6 & $\begin{array}{c}1.190 \\
(0.140)\end{array}$ & $\begin{array}{c}1.162 \\
(0.139)\end{array}$ & $\begin{array}{c}1.196 \\
(0.143)\end{array}$ & $\begin{array}{c}1.184 \\
(0.140)\end{array}$ & $\begin{array}{c}1.176 \\
(0.143)\end{array}$ \\
\hline \multicolumn{6}{|l|}{ women $(\mathrm{N}=2064)$} \\
\hline social skills & $\begin{array}{c}1.105^{* * *} \\
(0.036)\end{array}$ & $\begin{array}{c}1.106^{* * *} \\
(0.036)\end{array}$ & $\begin{array}{c}1.100^{* * *} \\
(0.037)\end{array}$ & $\begin{array}{c}1.106^{* * *} \\
(0.036)\end{array}$ & $\begin{array}{r}1.104^{* * *} \\
(0.037)\end{array}$ \\
\hline cognitive skills & $\begin{array}{l}1.078^{* *} \\
(0.034)\end{array}$ & $\begin{array}{l}1.074^{* *} \\
(0.034)\end{array}$ & $\begin{array}{l}1.071^{* *} \\
(0.034)\end{array}$ & $\begin{array}{l}1.079^{* *} \\
(0.034)\end{array}$ & $\begin{array}{l}1.074^{* *} \\
(0.035)\end{array}$ \\
\hline $\begin{array}{l}\text { cognitive skills } \\
\times \text { social skills }\end{array}$ & $\begin{array}{c}0.967 \\
(0.027)\end{array}$ & $\begin{array}{c}0.972 \\
(0.027)\end{array}$ & $\begin{array}{c}0.966 \\
(0.027)\end{array}$ & $\begin{array}{c}0.966 \\
(0.027)\end{array}$ & $\begin{array}{c}0.964 \\
(0.028)\end{array}$ \\
\hline O-Levels/ NVQ 2 & $\begin{array}{c}1.247^{* * *} \\
(0.080)\end{array}$ & $\begin{array}{c}1.205^{* * *} \\
(0.079)\end{array}$ & $\begin{array}{c}1.244^{* * *} \\
(0.081)\end{array}$ & $\begin{array}{c}1.246^{* * *} \\
(0.080)\end{array}$ & $\begin{array}{r}1.227^{* * *} \\
(0.082)\end{array}$ \\
\hline A-Levels/ NVQ 3 & $\begin{array}{c}1.577^{* * *} \\
(0.167)\end{array}$ & $\begin{array}{c}1.514^{* * *} \\
(0.165)\end{array}$ & $\begin{array}{c}1.575^{* * *} \\
(0.169)\end{array}$ & $\begin{array}{c}1.571^{* * *} \\
(0.167)\end{array}$ & $\begin{array}{r}1.551^{* * *} \\
(0.171)\end{array}$ \\
\hline degree/ NVQ 4-6 & $\begin{array}{c}1.498^{* * *} \\
(0.167)\end{array}$ & $\begin{array}{c}1.436^{* * *} \\
(0.162)\end{array}$ & $\begin{array}{c}1.508^{* * *} \\
(0.170)\end{array}$ & $\begin{array}{c}1.492^{* * *} \\
(0.167)\end{array}$ & $\begin{array}{r}1.457^{* * *} \\
(0.167)\end{array}$ \\
\hline
\end{tabular}

\section{included control variables}

family background

parenting

school characteristics

baseline covariates

\begin{tabular}{ll} 
& $\checkmark$ \\
& \\
$\checkmark$ & $\checkmark$ \\
$\checkmark$ & $\checkmark$ \\
& $\checkmark$ \\
\hline
\end{tabular}

Notes: The table displays hazard ratios and corresponding standard errors in parentheses. Missings in the variable on SES, education and added covariates were replaced by values as described in the appendix. Dummy variables indicating this were included in the estimation and partly significantly different from zero. ${ }^{* * *}$ indicates significance at the $99 \%$ level, ${ }^{* *}$ at the $95 \%$ level and ${ }^{*}$ at the $90 \%$ level. 
Table 5: Heterogeneity with respect to education

\begin{tabular}{|c|c|c|c|c|}
\hline & \multicolumn{2}{|c|}{ men } & \multicolumn{2}{|c|}{ women } \\
\hline & $\begin{array}{c}\text { without } \\
\text { interaction }\end{array}$ & $\begin{array}{c}\text { with } \\
\text { interaction }\end{array}$ & $\begin{array}{c}\text { without } \\
\text { interaction }\end{array}$ & $\begin{array}{c}\text { with } \\
\text { interaction }\end{array}$ \\
\hline social skills & $\begin{array}{l}1.060^{* *} \\
(0.028)\end{array}$ & - & $\begin{array}{c}1.105^{* * *} \\
(0.036)\end{array}$ & - \\
\hline if less than O-levels & - & $\begin{array}{c}1.121^{* * *} \\
(0.043)\end{array}$ & - & $\begin{array}{c}1.074 \\
(0.053)\end{array}$ \\
\hline if O-levels & - & $\begin{array}{l}0.990^{\ddagger} \\
(0.046)\end{array}$ & - & $\begin{array}{l}1.104^{*} \\
(0.058)\end{array}$ \\
\hline if A-levels & - & $\begin{array}{l}1.039 \\
(0.077)\end{array}$ & - & $\begin{array}{l}1.251^{* *} \\
(0.140)\end{array}$ \\
\hline if degree & - & $\begin{array}{l}1.098 \\
(0.114)\end{array}$ & - & $\begin{array}{c}1.148 \\
(0.137)\end{array}$ \\
\hline cognitive skills & $\begin{array}{c}1.042 \\
(0.030)\end{array}$ & - & $\begin{array}{l}1.078^{* *} \\
(0.034)\end{array}$ & - \\
\hline if less than O-levels & - & $\begin{array}{c}1.111^{* * *} \\
(0.044)\end{array}$ & - & $\begin{array}{c}1.126^{* * *} \\
(0.052)\end{array}$ \\
\hline if O-levels & - & $\begin{array}{l}1.020 \\
(0.053)\end{array}$ & - & $\begin{array}{l}1.075 \\
(0.056)\end{array}$ \\
\hline if A-levels & - & $\begin{array}{l}0.955^{\dagger} \\
(0.074)\end{array}$ & - & $\begin{array}{l}1.050 \\
(0.109)\end{array}$ \\
\hline if degree & - & $\begin{array}{c}0.886^{\dagger} \\
(0.099)\end{array}$ & - & $\begin{array}{c}0.930^{\dagger} \\
(0.091)\end{array}$ \\
\hline \multicolumn{5}{|c|}{ education at the mean of skills } \\
\hline O-levels & $\begin{array}{l}1.149^{* *} \\
(0.072)\end{array}$ & $\begin{array}{c}1.089 \\
(0.069)\end{array}$ & $\begin{array}{c}1.247^{* * *} \\
(0.080)\end{array}$ & $\begin{array}{c}1.224^{* * *} \\
(0.081)\end{array}$ \\
\hline A-levels & $\begin{array}{l}1.096 \\
(0.093)\end{array}$ & $\begin{array}{l}1.080 \\
(0.097)\end{array}$ & $\begin{array}{c}1.577^{* * *} \\
(0.167)\end{array}$ & $\begin{array}{c}1.488^{* * *} \\
(0.192)\end{array}$ \\
\hline degree & $\begin{array}{c}1.190 \\
(0.140)\end{array}$ & $\begin{array}{c}1.238 \\
(0.165)\end{array}$ & $\begin{array}{c}1.498^{* * *} \\
(0.167)\end{array}$ & $\begin{array}{c}1.587^{* * *} \\
(0.210)\end{array}$ \\
\hline number of observations & 2223 & 2223 & 2064 & 2064 \\
\hline \multicolumn{5}{|c|}{$\begin{array}{l}\text { Notes: The table displays hazard ratios and corresponding standard errors in } \\
\text { parentheses. The effect of cognitive (social) skills is assessed at the mean of social } \\
\text { (cognitive) skills, which is zero by construction. The same set of control variables as } \\
\text { used in the main model presented in Table } 2 \text { is included. A dummy variable indicating } \\
\text { whether there were missings in the information on the qualification level was included } \\
\text { but never significantly different from zero. }{ }^{* * *} \text { indicates significance at the } 99 \% \text { level, }{ }^{* *} \\
\text { at the } 95 \% \text { level and }{ }^{*} \text { at the } 90 \% \text { level. } \dagger \text { indicates that the hazard ratios are different } \\
\text { from the hazard ratios for the education level "less than O-levels" at the } 90 \% \\
\text { significance level. } \ddagger \text { denotes the corresponding significance at the } 95 \% \text { level. }\end{array}$} \\
\hline
\end{tabular}


Table 6: Means for different measures of social skills

\begin{tabular}{lcc}
\hline & men & women \\
\hline two scores for social skills & & \\
overreact & -0.147 & 0.159 \\
(standard deviation - overreact) & $(1.079)$ & $(0.881)$ \\
underreact & -0.094 & 0.102 \\
(standard deviation - underreact) & $(1.026)$ & $(0.962)$ \\
\hline categories of social skills (in percent) & \\
stable at the age of 7 & 55.24 & 70.59 \\
unsettled at the age of 7 & 28.34 & 19.82 \\
maladjusted at the age of 7 & 16.42 & 9.59 \\
\hline number of observations & 2223 & 2064 \\
\hline
\end{tabular}

Table 7: Investigating the measure for social skills

\begin{tabular}{lcc}
\hline \multicolumn{2}{c}{ men } & women \\
\hline using 2 scores for social skills & \\
\hline \hline overreact & 1.002 & $1.057^{*}$ \\
& $(0.025)$ & $(0.035)$ \\
underreact & $1.082^{* * *}$ & $1.071^{* *}$ \\
& $(0.029)$ & $(0.032)$ \\
cognitive skills & 1.045 & $1.081^{* *}$ \\
& $(0.030)$ & $(0.034)$ \\
cognitive skills $\times$ overreact & $0.949^{* *}$ & 0.971 \\
& $(0.021)$ & $(0.029)$ \\
cognitive skills $\times$ underreact & 0.986 & 0.992 \\
& $(0.023)$ & $(0.026)$ \\
\hline using categories of social skills & \\
\hline \hline unsettled & 0.971 & $0.863^{* *}$ \\
maladjusted & $(0.056)$ & $(0.058)$ \\
& $0.839^{* *}$ & $0.795^{* *}$ \\
cognitive skills if stable & $(0.067)$ & $(0.083)$ \\
& 1.014 & $1.065^{*}$ \\
cognitive skills if unsettled & $(0.038)$ & $(0.040)$ \\
cognitive skills if maladjusted & 1.064 & 1.040 \\
& $(0.048)$ & $(0.058)$ \\
\hline number of observations & $(0.072)$ & $(0.101)$ \\
\hline Notes The table & 2223 & 2064 \\
\hline
\end{tabular}

Notes: The table displays hazard ratios and corresponding standard errors in parentheses. The same set of control variables as used in the main model presented in Table 2 is included. ${ }^{* * *}$ indicates significance at the $99 \%$ level, ${ }^{* *}$ at the $95 \%$ level and ${ }^{*}$ at the $90 \%$ level. 
Table 8: Pearson correlation coefficients between skills at the age of 7 and 11

\begin{tabular}{lcccc}
\hline & cognitive 7 & social 7 & cognitive 11 & social 11 \\
\hline men & & & & \\
\hline \hline cognitive skills 7 & 1.00 & 0.41 & 0.69 & 0.32 \\
social skills 7 (BSAG) & 0.41 & 1.00 & 0.38 & 0.34 \\
women & & & & \\
\hline \hline cognitive skills 7 & 1.00 & 0.37 & 0.69 & 0.31 \\
social skills 7 (BSAG) & 0.37 & 1.00 & 0.36 & 0.36 \\
\hline
\end{tabular}

Table 9: Transition matrix of social skills at the age of 7 and 11

\begin{tabular}{|c|c|c|c|c|}
\hline & stable 11 & unsettled 11 & maladjusted 11 & total \\
\hline \multicolumn{5}{|c|}{ men $(N=1893)$} \\
\hline stable 7 & 67.48 & 22.80 & 9.72 & 56.52 \\
\hline unsettled 7 & 47.77 & 28.81 & 23.42 & 28.42 \\
\hline maladjusted 7 & 31.58 & 30.18 & 38.25 & 15.06 \\
\hline \multicolumn{5}{|c|}{ women $(\mathrm{N}=1788)$} \\
\hline stable 7 & 79.84 & 15.84 & 4.31 & 71.31 \\
\hline unsettled 7 & 57.14 & 29.71 & 13.14 & 19.57 \\
\hline maladjusted 7 & 42.94 & 31.90 & 25.15 & 9.12 \\
\hline total & 72.04 & 20.02 & 7.94 & 100 \\
\hline
\end{tabular}

Reading example for the table, upper panel: $56.52 \%$ of all men were in the category stable at the age of 7 . Of these, $67.48 \%$ were also in the category stable at the age of $11,22.8 \%$ were in the category unsettled at the age of 11 and $9.72 \%$ were in the category maladjusted at the age of 11 . At the age of $11,56.47 \%$ of men were in the category stable, $25.62 \%$ were in the category unsettled and $17.91 \%$ in the category maladjusted. 
Table 10: Comparing results for skills at the age of 7 and 11

\begin{tabular}{|c|c|c|c|c|}
\hline & $\begin{array}{l}\text { skills at the } \\
\text { age of } 7\end{array}$ & $\begin{array}{c}\text { skills at the } \\
\text { age of } 11\end{array}$ & $\begin{array}{c}\text { skills at the } \\
\text { age of } 7\end{array}$ & $\begin{array}{c}\text { skills at the } \\
\text { age of } 11\end{array}$ \\
\hline \multicolumn{5}{|c|}{ men $(\mathrm{N}=1893)$} \\
\hline social skills & $\begin{array}{c}1.076^{* * *} \\
(0.031)\end{array}$ & $\begin{array}{l}1.054^{*} \\
(0.030)\end{array}$ & - & - \\
\hline cognitive skills & $\begin{array}{c}1.009 \\
(0.031)\end{array}$ & $\begin{array}{c}1.049 \\
(0.034)\end{array}$ & - & $\begin{array}{l}- \\
-\end{array}$ \\
\hline $\begin{array}{l}\text { cognitive skills } \\
\times \text { social skills }\end{array}$ & $\begin{array}{l}0.946^{* *} \\
(0.023)\end{array}$ & $\begin{array}{c}0.968 \\
(0.025)\end{array}$ & - & - \\
\hline unsettled & - & - & $\begin{array}{c}0.952 \\
(0.060)\end{array}$ & $\begin{array}{l}0.889^{*} \\
(0.056)\end{array}$ \\
\hline maladjusted & - & - & $\begin{array}{l}0.817^{* *} \\
(0.073)\end{array}$ & $\begin{array}{c}0.906 \\
(0.078)\end{array}$ \\
\hline $\begin{array}{l}\text { cognitive skills } \\
\text { if stable }\end{array}$ & - & - & $\begin{array}{c}0.974 \\
(0.039)\end{array}$ & $\begin{array}{c}1.001 \\
(0.040)\end{array}$ \\
\hline $\begin{array}{l}\text { cognitive skills } \\
\text { if unsettled }\end{array}$ & - & - & $\begin{array}{c}1.029 \\
(0.050)\end{array}$ & $\begin{array}{l}1.096^{*} \\
(0.057)\end{array}$ \\
\hline $\begin{array}{l}\text { cognitive skills } \\
\text { if maladjusted }\end{array}$ & - & - & $\begin{array}{c}1.199^{* * *} \\
(0.082)\end{array}$ & $\begin{array}{l}1.179^{* *} \\
(0.084)\end{array}$ \\
\hline \multicolumn{5}{|c|}{ women $(\mathrm{N}=1788)$} \\
\hline social skills & $\begin{array}{c}1.099^{* * *} \\
(0.038)\end{array}$ & $\begin{array}{c}1.042 \\
(0.036)\end{array}$ & - & - \\
\hline cognitive skills & $\begin{array}{l}1.062^{*} \\
(0.035)\end{array}$ & $\begin{array}{c}1.137^{* * *} \\
(0.043)\end{array}$ & - & - \\
\hline $\begin{array}{l}\text { cognitive skills } \\
\times \text { social skills }\end{array}$ & $\begin{array}{c}0.956 \\
(0.028)\end{array}$ & $\begin{array}{c}0.984 \\
(0.032)\end{array}$ & - & - \\
\hline unsettled & - & - & $\begin{array}{c}0.902 \\
(0.065)\end{array}$ & $\begin{array}{l}0.879^{*} \\
(0.064)\end{array}$ \\
\hline maladjusted & - & - & $\begin{array}{l}0.789^{* *} \\
(0.090)\end{array}$ & $\begin{array}{c}0.835 \\
(0.106)\end{array}$ \\
\hline $\begin{array}{l}\text { cognitive skills } \\
\text { if stable }\end{array}$ & - & - & $\begin{array}{c}1.046 \\
(0.042)\end{array}$ & $\begin{array}{l}1.091^{* *} \\
(0.046)\end{array}$ \\
\hline $\begin{array}{l}\text { cognitive skills } \\
\text { if unsettled }\end{array}$ & - & - & $\begin{array}{c}1.003 \\
(0.060)\end{array}$ & $\begin{array}{c}1.319^{* * *} \\
(0.089)\end{array}$ \\
\hline $\begin{array}{l}\text { cognitive skills } \\
\text { if maladjusted }\end{array}$ & - & - & $\begin{array}{c}1.307^{* * *} \\
(0.115)\end{array}$ & $\begin{array}{c}0.996 \\
(0.108)\end{array}$ \\
\hline
\end{tabular}

Notes: The table displays hazard ratios and corresponding standard errors in parentheses. Further control variables in the estimation are education, the father's SES at the age of 7 and 11, whether the individual is married at the beginning of the spell, has children, was employed before, the season of the year, the claimant count rate, the region of residence, year dummies and the piecewise constant time specification. ${ }^{* * *}$ indicates significance at the $99 \%$ level, ${ }^{* *}$ at the $95 \%$ level and ${ }^{*}$ at the $90 \%$ level. 
Table 11: Means of variables by whether an individual was unemployed before the age of 23 or not

\begin{tabular}{|c|c|c|c|c|}
\hline Variables & $\begin{array}{l}\text { NEVER } \\
\text { mean }\end{array}$ & $\begin{array}{l}\text { NEMPLOYED } \\
\text { standard } \\
\text { deviation }\end{array}$ & $\begin{array}{l}\text { UNEI } \\
\text { mean }\end{array}$ & $\begin{array}{l}\text { IPLOYED } \\
\text { standard } \\
\text { deviation }\end{array}$ \\
\hline female & 0.52 & & 0.48 & \\
\hline cognitive skills & 0.07 & 0.97 & -0.09 & 1.03 \\
\hline social skills & 0.08 & 0.96 & -0.11 & 1.05 \\
\hline stayed on at school after age 16 & 0.29 & & 0.26 & \\
\hline \multicolumn{5}{|c|}{ socio-economic status of father at the age of 7} \\
\hline low & 0.20 & & 0.25 & \\
\hline medium & 0.53 & & 0.51 & \\
\hline high & 0.20 & & 0.17 & \\
\hline no male head of household & 0.02 & & 0.03 & \\
\hline missing & 0.04 & & 0.05 & \\
\hline \multicolumn{5}{|c|}{ region of residence at the age of 16} \\
\hline Wales & 0.05 & & 0.07 & \\
\hline North & 0.06 & & 0.10 & \\
\hline North West & 0.11 & & 0.15 & \\
\hline E \& W.Riding & 0.08 & & 0.09 & \\
\hline North Midlands & 0.09 & & 0.07 & \\
\hline Midlands & 0.10 & & 0.10 & \\
\hline East & 0.10 & & 0.07 & \\
\hline South East & 0.16 & & 0.13 & \\
\hline South & 0.07 & & 0.06 & \\
\hline South West & 0.07 & & 0.06 & \\
\hline Scotland & 0.10 & & 0.11 & \\
\hline number of observations & 5843 & & 4287 & \\
\hline
\end{tabular}


Table 12: Probit estimations: Probability of experiencing unemployment of at least two weeks until the age of 23

\begin{tabular}{|c|c|c|c|c|}
\hline \multirow[b]{2}{*}{ Specification } & \multicolumn{2}{|c|}{ men } & \multicolumn{2}{|c|}{ women } \\
\hline & (a) & (b) & (a) & (b) \\
\hline cognitive skills & $\begin{array}{c}-0.020^{* *} \\
(0.006)\end{array}$ & $\begin{array}{l}-0.009 \\
(0.007)\end{array}$ & $\begin{array}{c}-0.020^{* *} \\
(0.007)\end{array}$ & $\begin{array}{l}-0.013 \\
(0.007)\end{array}$ \\
\hline social skills & $\begin{array}{c}-0.040^{* * *} \\
(0.006)\end{array}$ & $\begin{array}{c}-0.034^{* * *} \\
(0.006)\end{array}$ & $\begin{array}{c}-0.026^{* * *} \\
(0.007)\end{array}$ & $\begin{array}{c}-0.020^{* *} \\
(0.007)\end{array}$ \\
\hline $\begin{array}{l}\text { stayed on at school } \\
\text { after age } 16\end{array}$ & $\begin{array}{c}0.014 \\
(0.014)\end{array}$ & $\begin{array}{l}0.034^{*} \\
(0.015)\end{array}$ & $\begin{array}{c}0.005 \\
(0.014)\end{array}$ & $\begin{array}{l}0.008 \\
(0.014)\end{array}$ \\
\hline \multicolumn{5}{|c|}{ socio-economic status of father at the age of 7} \\
\hline high SES & $\begin{array}{c}-0.081^{* * *} \\
(0.018)\end{array}$ & $\begin{array}{l}-0.039 \\
(0.020)\end{array}$ & $\begin{array}{c}-0.024 \\
(0.018)\end{array}$ & $\begin{array}{l}-0.038 \\
(0.020)\end{array}$ \\
\hline medium SES & $\begin{array}{c}-0.056^{* * *} \\
(0.014)\end{array}$ & $\begin{array}{l}-0.031^{*} \\
(0.015)\end{array}$ & $\begin{array}{l}-0.021 \\
(0.014)\end{array}$ & $\begin{array}{l}-0.022 \\
(0.015)\end{array}$ \\
\hline number of observations & 5,024 & 5,024 & 5,106 & 5,106 \\
\hline \multicolumn{5}{|c|}{ included control variables } \\
\hline region at the age of 16 & $\checkmark$ & $\checkmark$ & $\checkmark$ & $\checkmark$ \\
\hline family background & & $\checkmark$ & & $\checkmark$ \\
\hline parenting & & $\checkmark$ & & $\checkmark$ \\
\hline school characteristics & & $\checkmark$ & & $\checkmark$ \\
\hline
\end{tabular}

Notes: The table displays average partial effects, calculated using the Stata command "margeff" written by Tamás Bartus. Standard errors obtained from the same command are reported in parentheses, they are derived using the delta method. Significance levels correspond to those of the coefficients. Having a father of low SES or not having a male head of household is the base category for father's SES. See Appendix B for a detailed list of control variables. Missings in covariates were replaced by values as explained in Appendix A and dummy variables indicating this were included in the estimation. These were partly significant in the estimation. ${ }^{* * *}$ indicates significance at the $99 \%$ level, ${ }^{* *}$ at the $95 \%$ level and ${ }^{*}$ at the $90 \%$ level. 
Figure 3: Effect of a one standard deviation increase in cognitive and social skills on the hazard ratio, specification controlling for education
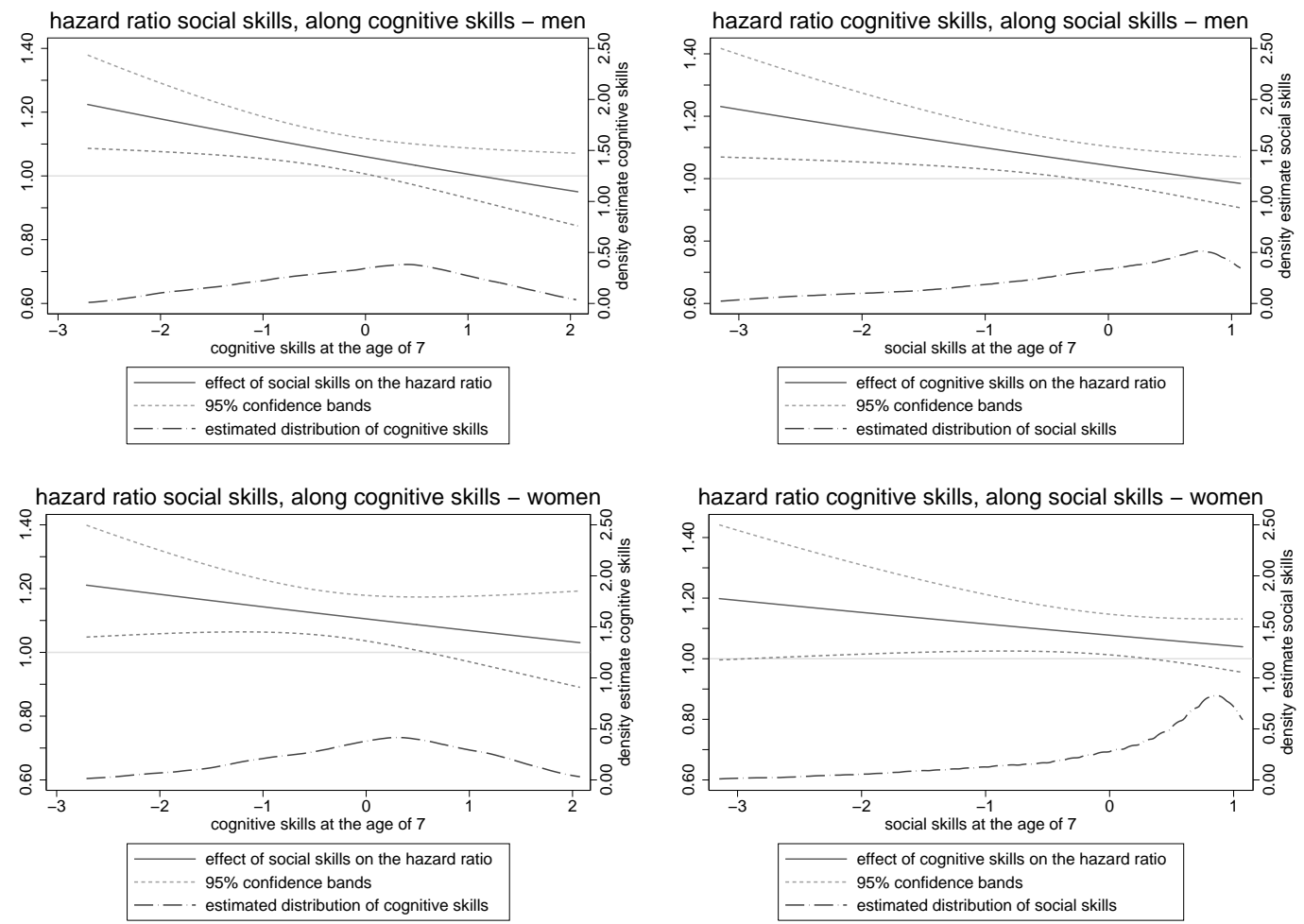

Notes: The depicted hazard ratio for cognitive skills is calculated using the estimated coefficients in the following way (correspondingly for social skills):

hazard ratio cognitive $=\exp \left\{\beta_{\text {cognitive }}+\right.$ social $\left.\cdot \beta_{\text {cognitive } \cdot \text { social }}\right\}$ 
Figure 4: Effect of being unsettled or maladjusted as opposed to stable at the age of 7 and 11 on the hazard ratio, using the smaller sample
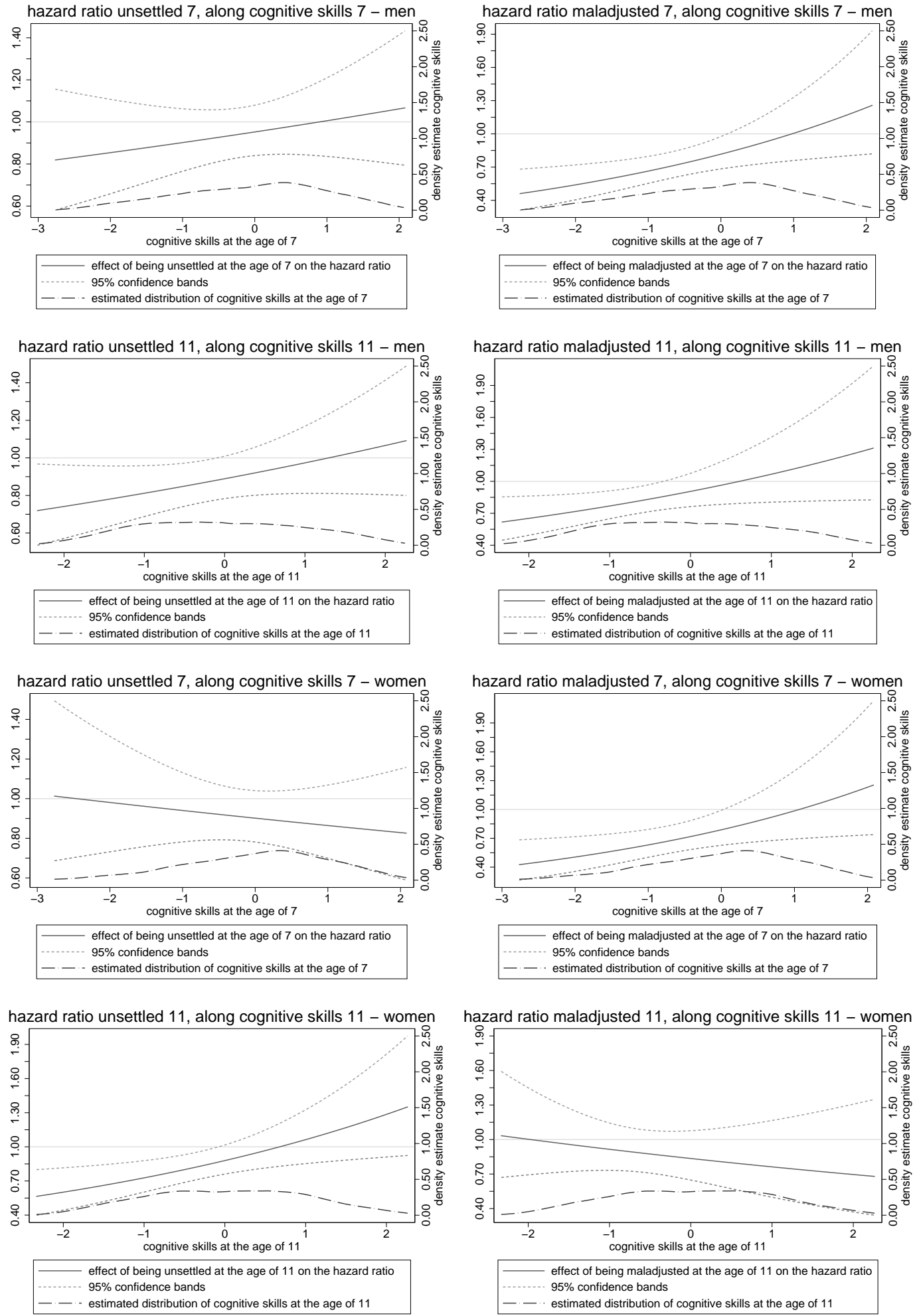

Notes: The depicted hazard ratio for being in the category maladjusted as opposed to stable is calculated using the estimated coefficients in the following way (correspondingly for being in category unsettled):

hazard ratio $_{\text {maladjusted }}=\exp \left\{\beta_{\text {maladjusted }}+\right.$ cognitive $\left.\cdot \beta_{\text {cognitive.maladjusted }}\right\}$ 